\title{
PREPARING FOR A LEGAL EPIDEMIC: AN AIDS PRIMER FOR LAWYERS AND POLICY MAKERS*
}

\author{
TODD DUCHARME**
}

\begin{abstract}
The author examines AIDS-related legal developments in Canada and the United States, and provides an overview of the scientific and medical issues implicated therein.

The leper who has the disease shall wear torn clothes and let the hair of his head hang loose, and he shall cover his upper lip and cry, "Unclean, unclean." He shall remain unclean as long as he has the disease; he is unclean; he shall dwell alone in a habitation outside the camp....

This is the law for a leprous disease. . .'
\end{abstract}

\section{INTRODUCTION}

Disease is a complex phenomenon. To understand it we must be cognizant not only of its biological dimensions but also its social construction, i.e., how the biological fact of disease is mediated by social praxis. This involves how society views both a disease per se, and its victims. On a biological level, the ancient Israelites did not understand leprosy. They exaggerated its contagiousness and the severity of its health consequences. They also considered a variety of other skin diseases, as well as blemishes affecting clothing and buildings, to be leprosy. Ignorance about the disease and fear of death were the central determinants of their social response to it; leprosy came to be viewed not simply as a disease but as a form of divine retribution, with lepers being considered unclean physically, morally and spiritually. As a result, lepers were shunned and even stoned. Finally the Israelites, through Moses and Aaron, turned to their Lawgiver for instructions on how to deal with this social problem. ${ }^{2}$

Medically AIDS (Acquired Immune Deficiency Syndrome) is not at all similar to leprosy. Despite this, the parallels to the modern day response to AIDS are striking. AIDS is particularly challenging in both its biological and social dimensions. On the biological level, AIDS is a terrible disease. Its victims face emaciation, disfigurement, disability and eventually a slow and painful death. Although our knowledge of the disease has increased rapidly, and continues to do so, there is still much about AIDS which we do not know. On the social level, the disease is still generally misunderstood and its contagiousness in particular is exaggerated. ${ }^{3}$ Perhaps even more significantly, AIDS forces society to confront many of its taboos: same-sex

- The author would like to thank the staff of the Federal Centre for AIDS, Ottawa for their generous assistance and Robin Geller and Mark Kingwell for their helpful comments.

* Executive Director, Centre for Constitutional Studies, Faculty of Law, University of Alberta.

1. The New Oxford Annotated Bible, RSV, Lev 13:45, 46 and 59.

2. In Canada the legal response to leprosy came in the form of the Leprosy Act 6 Edw. VII, $c$. 24. which provided for the institutionalization of lepers and made it an offence to harbour a person suffering from leprosy. The Leprosy Act was repealed by S.C. 1970, c. 13, which received Royal Assent on February 11, 1971.

3. Alberta Community and Occupational Health, The Alberta AIDS Survey December 1987. This survey of 1,000 adults and 500 teenagers found that, despite a high knowledge of the major routes of HIV transmission, 9 to $15 \%$ of those Albertans surveyed still were concerned about contracting AIDS through casual contact. 
sex; defiance of traditional forms of family organization; “deviant" abuse of drugs; and death. Indeed, even the body fluids that are implicated in the transmission of the disease, blood, semen and vaginal secretions, are traditionally seen as symbols of "impurity, pollution, danger and defilement"..As a result, people with AIDS (PWAs) are discriminated against in almost every sphere of their lives. Far too often they face rejection by friends and family and stigmatization by society, leaving them alone to face "the double jeopardy of lethal disease and social oppression". There have been proposals for their quarantine and, most incredibly, AIDS has been described by some as a divine judgment against homosexuals. ${ }^{6}$

Finally, we too have turned to our "lawgiver" to determine how the problem should be dealt with. Courts, human rights tribunals, labour arbitrators, legislatures, city councils, school boards, etc., are beginning to face a wide array of AIDS-related issues. While this legal response is devoid of the religious meaning of that of the Israelites, it is nonetheless a critical part of our social response to AIDS. Symbolically, this response constitutes a formal expression of our society's attitude towards PWAs. Practically, the legal response will determine, to a large extent, how much extra suffering the victims of this horrific disease will be made to endure.

To date, very little has been written in Canada about the legal aspects of AIDS. ' This stands in sharp contrast to the situation in the United States where books, ${ }^{8}$ reporters, ${ }^{9}$ law reviews, ${ }^{10}$ and scores of articles have been

4. L. Eisenberg, "The Genesis of Fear: AIDS and the Public's Response To Science" (1986) 14 Law, Medicine \& Health Care 243, 245.

5. A.M. Brandt, "From Social Meaning to Social Policy" (1986) 14 Law, Medicine \& Health Care 231, 241.

6. Adrian Forsyth, "The Plague Within" Equinox (Nov/Dec 1987) 88; "Churches Cool to Vigil for AIDS Victims", Edmonton Journal, (September 3, 1986) p. B3; A Study of 208 Families In Lethbridge, Alberta found that $14 \%$ of those who responded cited divine retribution as the cause of AIDS; "Canadians Know Little About AIDS, Survey Finds", Globe and Mail, (August 13, 1987) p. A15.

7. M. Mackinnon and H. Krever, "Legal and Social Aspects of AIDS in Canada" in Royal Society of Canada, AIDS: A Perspective For Canadians (1988); M. Sommerville and N. Gilmore, Human Immunodeficiency Virus Antibody Testing in Canada (1988); M. Sommerville, Structuring the Legal and Ethical Issues Raised by AIDS, Conference Proceedings AIDS: Social Policy, Ethics and the Law, Monash University, Australia (1986); Canadian Bar Association - Ontario, Report of the Canadian Bar Association - Ontario Committee to Study the Legal Implications of Acquired Immunodeficiency Syndrome (AIDS) (1986); B.J. Johnson and C.L. Soskolne, "AIDS: medicolegal considerations for Canadian hospitals" CMAJ (1986) 135:1091-1096; J.D. McGinnis, "Review of Report of the Canadian Bar Association-Ontario Committee to Study the Legal Implications of Acquired Immunodeficiency Syndrome (AIDS)" (1987) 66 Can. Bar Rev. 408-12. There have also been a variety of seminars conducted by Provincial Bar Associations, etc.

8. AIDS and the Law. A Guide for the Public, eds. H.L. Dalton and S. Burris (1987). Hereinafter referred to as $A \& L I ; A I D S$ and the Law, ed. W.H.L. Dornette (1987). Hereinafter referred to as $A \& L I I$.

9. AIDS Policy \& Law (BNA) is a bi-weekly newsletter. Hereinafter referred to as APL; AIDS Update available from Lambda Legal Defense and Education Fund is a monthly summary of AIDS-related legal developments. Hereinafter referred to as $A U$; AIDS cases are also reported in Lesbian/Gay Law Notes, a monthly newsletter published by the Bar Assoc. for Human Rights of Greater New York. Hereinafter referred to as $L / G L N$. The ACLU has also published summaries of 53 cases involving AIDS in Legal Docket: AIDS and the Law, Sexuality and the Law. (July 1987). Hereinafter referred to as $A C L U$.

10. (1985) 14 Hofstra L.R. pp. 1-209, (1987) 15 Law, Medicine \& Health Care pp. 1-89; and (1988) 7 St. Louis Public L. Rev. pp. 1-207 were devoted to AIDS and the Law. 
devoted to the subject. "This reflects the greater spread of the disease in the United States, which has in turn led to a greater number of AIDS-related legal developments there. However, the relatively recent emergence of the legal dimensions of the problem in Canada complicates the job of the lawyer or policy maker confronted with an AIDS-related issue.

A principled legal response to any AIDS-related issue is virtually impossible without a thorough understanding of the medicine and science of AIDS. Unfortunately this is a complex area, made even more so by the relatively recent recognition of the disease. Moreover, it is difficult, if not impossible, to keep abreast of all the ongoing research on AIDS. What is a difficult task for a medical expert, is that much more daunting for lawgivers, who not only lack omniscience, but are also medical laypersons. While a variety of sources of AIDS information exist, their utility for the legal actor is limited in several respects. First, much of the medical literature is very technical and difficult to understand for someone without a background in life sciences. Second, medical research, like legal research, requires a familiarity with periodicals and other resources that most medical laypersons lack. Third, much of the material written about AIDS for the medical layperson is simplistic, limited in scope and/or fails to consider the full range of questions a lawyer or policy maker would have to address in dealing with an AIDS issue.

This paper attempts to remedy this problem by: (i) outlining some of the areas of the law where AIDS-related issues are likely to become important; (ii) indicating what resources are available for legal and medical research on AIDS; and (iii) providing a summary of current medical and scientific knowledge about AIDS. ${ }^{12}$ Part I will outline briefly the history of our knowledge of AIDS and its epidemiology. Part II will consider some examples of the legal response to AIDS from Canada and the United States in order to determine what sort of medical questions are likely to be significant in the legal context. Part III will address three medical questions: the immunopathogenesis of AIDS; the transmission routes of AIDS; and the clinical spectrum of AIDS.

The other significant scientific issue, which is implicated in virtually all AIDS-related legal problems, is testing for AIDS. Testing for AIDS raises a host of complicated questions relating to both the limitations of the available diagnostic technologies and the proper design and use of testing programmes. ${ }^{13}$ There is not yet a test for the Human Immunodeficiency

11. Perhaps the best indication of the amount of scholarship in this field is the fact that the Current Law Index published by the American Association of Law Libraries has several separate AIDS-related subject headings and has listed over 250 articles since 1983.

12. This paper reflects the medical and scientific information about AIDS published as of May 1 , 1988. Given the rapid pace of developments in this area this information must be updated continually.

13. M.T. Shecter et al., "HIV Antibody Testing Programs" in AIDS: A Perspective For Canadians, supra, note 7; R. Fraser et al., "Public Health Imperatives of HIV Infection and AIDS in Canada" in AIDS: A Perspective For Canadians, supra, note 7; J.W. Frank et al., "A Critical Look At HIV-Antibody Tests: 2. Benefits, Risks and Clinical Use" Can. Fam. Physician (1987) 33:2229-35; R. Bayer et al., "HIV Antibody Screening An Ethical Framework for Evaluating Proposed Programs" JAMA (1986) 256: 1768-1774; L.O. Gostin et al.," The Case Against Compulsory Casefinding in Controlling AIDS - Testing, Screening and Reporting" (1986) 12 Am. J. of Law \& Medicine 7. 
Virus (HIV) itself, i.e., the retrovirus which causes AIDS. ${ }^{14}$ Rather the two tests which currently are used in sequence, the enzyme-linked immunosorbent assay (ELISA) and the Western Blot, are tests for HIV antibodies. Perhaps the most important point to note here is that these tests are far from reliable and, especially in a population with a low prevalence of HIV infection, can produce both false positive and false negative results. ${ }^{15} \mathrm{HIV}$ testing also raises a variety of legal issues relating to individual autonomy, confidentiality and the power of the state. ${ }^{16}$ The many questions with respect to HIV testing are beyond the scope of this work and will be addressed in a subsequent paper.

\section{AIDS: HISTORY AND EPIDEMIOLOGY}

\section{A. HISTORY}

What is now known as AIDS was first described in 1981 by the U.S. Centers for Disease Control (CDC). On June 5, 1981, the CDC reported that five previously healthy young men from Los Angeles, all of whom were active homosexuals, had developed pneumocystic carinii pneumonia (PCP). ${ }^{17}$ Almost two months later the CDC reported that Kaposi's Sarcoma (KS), a cancer of the blood vessels, had been diagnosed in a cohort of twenty-six men from New York City and California. ${ }^{18}$ Some of the latter group also presented with PCP. The first reported AIDS case in Canada in February, 1982, involved the diagnosis of PCP in a homosexual male from Ontario. ${ }^{19}$ The occurrence of these two diseases in these groups was curious, albeit for different reasons. The cases of KS were unusual because it previously had been diagnosed most commonly among older men of Mediterranean descent and black Africans. The cases of PCP had

14. This retrovirus has been assigned a variety of names, e.g., Lymphadenopathy-associated Virus (LAV), Human T-Cell Lymphotropic Virus Type III (HTLV-III) and AIDS-associated Retrovirus (ARV). However, in this paper it will be referred to as the Human Immunodeficiency Virus (HIV) in accordance with the recommendations of the International Committee on the Taxonomy of Viruses: Coffin, et al. "Human Immunodeficiency Viruses" [Letter] Science (1986) 232:697.

15. Depending on the prevalence of HIV infection in the population being tested and whether or not the tests are being performed at proficiency or best case levels the false positive rate could vary from under $0.1 \%$ (best case testing of a population with an HIV seroprevalence of $10 \%$ ) to almost $90.0 \%$ (proficiency testing of a population with an HIV seroprevalence of $0.01 \%$ ). For the same populations the false negative rate could range from $0.008 \%$ to $10 \%$ : Testimony of Mr. L. Miike, Office of Technology Assessment, Before the United States House of Representatives Committee on Small Business Regulation and Business Opportunities, AIDS Antibody Testing, October 19, 1987. See also K.B. Meyer and S.G. Pauker. "Screening for HIV: Can We Afford the False Positive Rate?" N Eng J Med (1987) 317:238-241; J.W. Frank et al., "A Critical Look At HIV-Antibody Tests: 1. How Accurate Are They?", Can. Fam. Physician (1987) 33:2005-2011; R.A. Coates and J.K. Johnson, "Validity of Tests for HIV Infection" in AIDS: A Perspective For Canadians, supra, note 7; M.J. Barry et al., "Screening for HIV Infection: Risks, Benefits and the Burden of Proof" (1986) 14 Law, Medicine \& Health Care 259.

16. MacKinnon and Krever, supra, note 7; Sommerville and Gilmore, supra, note 7.

17. "Pneumocystis Pneumonia - Los Angeles", Morbidity \& Mortality Weekly Reports (MMWR) (1981) 30:250-52.

18. "Kaposi's Sarcoma and Pneumocystic Pneumonia Among Homosexual Men - New York City and California" MMWR (1981) 30:305-8.

19. "Pneumocystic Carinii Pneumonia in a Homosexual Male, Ontario", Can Dis Wkly Rep (1982) 8:65-8. 
been found almost exclusively in severely immunosuppressed patients and there was no clinically apparent underlying immunodeficiency in these previously healthy men.

By June, 1982, the CDC had received more than 350 reports of KS and/ or serious opportunistic infections (OIs). ${ }^{20}$ While a variety of explanations were advanced, the simplest was that these illnesses were caused by a transmissible agent which somehow severely altered immune regulation. ${ }^{21}$ During 1983-84, three groups of researchers, working independently in France ${ }^{22}$ and the United States, ${ }^{23}$ identified a retrovirus believed to be the etiologic agent of AIDS. Subsequent investigations have demonstrated that these three studies had all identified essentially the same retrovirus and that it is in fact causally involved in both AIDS and AIDS-related disorders. ${ }^{24}$

\section{B. EPIDEMIOLOGY}

Since 1981 AIDS has spread rapidly. In the United States the number of AIDS cases reported doubled every 5 months in 1982, every 11 months in 1985 and every 13 months in $1986 .{ }^{25}$ By June, 1988, 65,780 cases of AIDS had been reported in the United States. ${ }^{26}$ AIDS cases have been reported

20. Opportunistic infections are so called because they result from exposure to infectious agents which ordinarily could be resisted successfully but for the failure of the AIDS victim's immune system.

21. Other hypotheses included the possibility that AIDS was a new result of an already known infection or that it was a result of immune system collapse as a result of the high exposure to microbes seen in the homosexual population and the large number of donor's antigens seen in haemophiliacs: J.E. Osborn, "The AIDS Epidemic: Discovery of a New Disease" $A \& L I$, supra, note 8, at 20.

22. J.C. Charmann et al., "Isolation of a T-lymphotropic Retrovirus from a Patient at Risk for Acquired Immune-Deficient Syndrome (AIDS) Science (1983) 220:868-71.

23. R.C. Gallo et al., "Detection, Isolation and Continuous Production of Cytopathic Retroviruses (HTLV-III) from Patients with AIDS and Pre-AIDS" Science (1984) 224:497500; Levy et al. " "Isolation of Lymphocytopathic Retroviruses from San Francisco Patients with AIDS" Science (1984) 225:840-1.

24. A second retrovirus from the HIV family, HIV-2, has been isolated from patients in west Africa. However, it has not yet been found in North America: F.C. Clavel et al., "Human Immunodeficiency Virus Type 2 Infection Associated with AIDS in West Africa" $N$ Eng $J$ Med (1987) 316:1180.

25. Understanding AIDS and HIV Infection. Information for Hospitals and Health Professionals, (1987) Ontario Ministry of Health, at 15. Hereinafter cited as Understanding AIDS. $N . B$. The number of reported cases is likely to be lower than the actual number of AIDS cases for several reasons: (i) The original CDC case definition of AIDS, which was revised on August 14, 1987 (see MMWR (1987) 36:3s to 9s), did not include certain diseases which are now recognized as being indicative of AIDS; (ii) The possibility of under ascertainment in cases where the victim dies of one of the AIDS-related opportunistic diseases before AIDS is diagnosed; and (iii) the possibility that some AIDS victims may commit suicide rather than face the physical, psychological, social and financial problems that afflict PWAs. This factor might be further complicated by suicides made to look like accidental deaths in order to preserve insurance benefits for survivors. One study has found that men aged 20 to 59 years with a diagnosis of AIDS are 36 times as likely to commit suicide than the general population: P. M. Marzuk et al. "Increased Risk of Suicide in Persons with AIDS" JAMA (1988) 259:133-7.

26. Federal Centre for AIDS, Surveillance Update: AIDS in Canada July 4, 1988, at 8. Hereinafter Surveillance Update. 
from all 50 States and the District of Columbia, ${ }^{27}$ and the total number of HIV infected individuals in the United States has been estimated to be between 500,000 and $1,000,000 .{ }^{28}$ Furthermore, the U.S. Public Health Service calculates that by the end of 1991 there will be more than 270,000 cases which meet the CDC definition. ${ }^{2}$

While the number of AIDS cases reported in Canada is much lower on a proportional basis, ${ }^{30}$ the spread of the disease has been similarly rapid. By July 4, 1988, 1,809 cases of AIDS have been reported to the Federal Centre for AIDS and the number of reported cases is doubling every seventeen months. ${ }^{31}$ Cases of AIDS have been reported in every province as well as the Yukon and the Northwest Territories. Estimates of the number of seropositive persons in Canada range from 30,000 to $75,000 .{ }^{32}$ The long term prospects are similarly bleak with 3,953 to 6,974 cases expected by the year $1991 .{ }^{33}$

The high risk groups for AIDS in Canada and the U.S. are the same, although their relative importance as a percentage of the total number of cases differs. Most AIDS victims are homosexual or bisexual males, comprising $82.9 \%$ of the total cases in Canada and $73 \%$ of the cases in the U.S. ${ }^{34}$ The remaining cases in Canada are: (i) Persons from an endemic area - 4.8\%; (ii) Recipients of blood products - 4.9\%; (iii) Other/Cause Unknown - 2.8\%; (iv) Heterosexual partners of a high risk individual $2.4 \%$; and (v) Intravenous (IV) drug abusers - .66\%. ${ }^{35}$ The other cases in the U.S. are (i) IV drug abusers - $17 \%$; (ii) Heterosexual contact $-4 \%$; (iii) Others/Cause Unknown - 3\%; and (iv) recipients of blood products $-3 \% .^{36}$ In both Canada and the U.S., AIDS has been found in children who have either received blood products or who have contracted the disease from their mothers during pregnancy or childbirth.

27. Coolfont Report: A PHS Plan for Prevention and Control of AIDS and the AIDS Virus, A Public Health Rep (1986) 101:341-348 at 342. Hereinafter referred to as Coolfont Report.

28. J.W. Curran et al. "The Epidemiology of AIDS: Current Status and Future Prospects" Science (1985) 229:1352-1357. It has been argued that the 50:1 to 100:1 infected-to-AIDS ratio used by Curran is too high: Schecter, supra, note 13.

29. Id.

30. The rate for $1,000,000$ is 69.8 in Canada and 263.1 for the United States: Surveillance Update, supra, note 26 , at 8.

31. Id.

32. Statement of Dr. Norbert Gilmore, chairman of the National Advisory Committee on AIDS, Jan 14, 1988: APL 3:1 Jan 27, 1988. If the 23:1 infected-to-AIDS ratio recommended by Schecter, supra, note 13, is used the number of seropositive persons in Canada would be approximately 42,000 . N.B. The term seropositive indicates that a person has tested positive for HIV antibodies. In this paper the term will be used to mean HIV-infected.

33. Surveillance Update, supra, note 26.

34. Surveillance Update, supra, note 26, p. 2; MMWR (1988) 37:286-295. N.B. the Federal Centre for AIDS and the CDC keep separate totals for homosexual/bisexual males and homosexual IV drug users. The percentage of the total cases from these groups are $80.5 \%$ and $2.4 \%$ in Canada and $65 \%$ and $8 \%$ in the United States. I have combined these two figures to get the above totals for homosexual or bisexual males.

35. Surveillance Update, supra, note 26.

36. MMWR (1988) 18:286-295. N.B. The CDC keeps separate statistics for haemophiliacs and recipients of blood transfusions. The percentage of the total cases from these groups are $1 \%$ and 2\% respectively. As this is not done in Canada I have combined these two groups into one category for ease of comparison. 


\section{THE LEGAL RESPONSE TO AIDS}

\section{A. LEGISLATION}

All levels of government are faced with the necessity of developing policies with respect to AIDS. The need for a clear policy on AIDS is particularly apparent where the government is in the position of employer or is charged with the operation of institutions such as schools, hospitals, prisons, etc. The Constitution Act, $1867^{37}$ did not assign "public health" as an independent head of power to either the federal or provincial governments. ${ }^{38}$ Rather, the federal government was granted the power to regulate quarantine and marine hospitals (s. 91(11)) while the provinces were given the power to regulate other hospitals (s. 92(7)). However, as a constitutional matter, both the federal and provincial governments have the power to legislate with respect to a wide variety of AIDS-related issues.

Parliament under its peace, order and good government powers can pass legislation dealing with matters of national concern or affecting national welfare such as "pestilences" or "epidemics". ${ }^{39}$ Parliament also has the power to legislate in response to a national emergency. ${ }^{40}$ However, this power is less likely to be significant with respect to AIDS as legislation enacted in this way must be temporary. ${ }^{41}$ Other potential sources for AIDSrelated legislation are the federal powers over criminal law (s. 91(27)), immigration (s. 91(25)), the military (s. 91(7)), penitentiaries (s. 91(28)), status Indians (s. 91(24)) and in the sphere of labour relations..$^{42}$

In addition to their authority over hospitals (s. 92(7)), the provinces have general jurisdiction over public health as a matter of local or private nature (s. 92(16)). ${ }^{43}$ The provincial power over property and civil rights (s. 92(12)) will also be very important with respect to AIDS encompassing as it does labour relations, ${ }^{4}$ human rights legislation, ${ }^{45}$ regulation of the insurance

37. (U.K.) 30 \& 31 Vict. c. 3 (formerly British North America Act, 1867).

38. On the question of jurisdiction over public health see: $A$. Lajoie and P.A. Molinari, "Partage Constitutionel des Compétences en Matière de Santé au Canada" (1978) 56 Can. Bar Rev. 579; R.T. McKall, "Constitutional Jurisdiction Over Public Health"(1974)6 Man. L. J. 317.

39. Schneider v. The Queen [1982] 2 S.C.R. 112, 141; Toronto Electric Commissioners v. Snider [1925] A.C. 396, 412; A.G. Ont. v. Canada Temperance Federation [1946] A.C. 193, 205; Labatt Breweries of Canada Ltd. v. A.G. Can. [1980] I S.C.R. 914, 934.

40. Re Anti-Inflation Act [1976] 2 S.C.R. 373.

41. Id., at $427,437,461$, and 467 .

42. The federal government has jurisdiction over labour relations in industries otherwise within federal competence, e.g., Shipping and Navigation (s. 91(5)), the Postal Service (s. 91(5)), Banking (s. 91(15)), and Interprovincial Works and Undertakings (ss. 92(10) and 91(29)): $R e$ Industrial Relations and Disputes Investigation Act (Can.) [1955] S.C.R. 529; as well as over the federal public service: C.L.R.B. v. Yellowknife [1977] 2 S.C.R. 729; A.G. Can. v. St. Hubert Base Teachers' Assoc. [1983] 1 S.C.R. 498.

43. Schneider, supra, note 39. The breadth of provincial power with respect to the protection of public health is illustrated by the following: Fawcett v. A.G. Ont. [1964] S.C.R. 625; Re Bowack (1892) 2 B.C.L.R. 216; and Green v. Livermore [1940] O.R. 381.

44. Toronto Electric Commissioners, supra, note 39; A.G. Can. v. A.G. Ont. (Labour Conventions) [1937] A.C. 326; C.P.R. v. A.G. B.C. (Empress Hotel) [1950] A.C. 122.

45. R. ex rel. Nutland v. McKay [1956] 5 D.L.R. (2d.) 403. 
industry, ${ }^{46}$ the manufacture and sale of drugs, ${ }^{47}$ and the regulation of the medical, dental and other professions. ${ }^{48}$ Also likely to be important in this regard are the provincial powers over provincial prisons (s. 92(6)), municipal institutions (s. 92(8)), and the administration of justice (s. 92(14)).

In terms of policy both the federal and provincial governments are involved in the development of a variety of policies relating to AIDS. ${ }^{49}$ To this end, the Federal Centre for AIDS was established in 1985 to study and monitor the disease and the Federal government is currently developing a national strategy to respond to AIDS..$^{50}$ While no AIDS-specific legislation has been enacted to date in Canada, two other legislative responses to AIDS have occurred. First, legislation relevant to, and arguably motivated by, concerns about AIDS has been enacted without any specific reference to AIDS. Second, regulations and policies explicitly dealing with AIDS have been adopted. Of course, in addition to these new developments there are other existing statutes which are relevant to AIDS.

One obvious example of the first type of indirect legislative response mentioned above are the recent amendments to the Public Health Act of Alberta. ${ }^{\text {s1 }}$ While there was no mention of AIDS in these amendments, the Community Health Minister, Jim Dinning, justified them by referring to anecdotal accounts of two Albertan PWAs who continued to "act irresponsibly" after learning of their condition. ${ }^{32}$ Furthermore, during the legislative debate the amendments were discussed by members of the opposition as being directed towards AIDS. ${ }^{33}$

The amendments in question broadened the grounds for: (i) the quarantine under s. 54 of a person infected with a communicable disease; and (ii) the apprehension and confinement, pursuant to s. 49 or s. 57, of a person believed to be infected with a communicable disease. Under the old Act the grounds for quarantine under s. 54 were that the person refused or neglected to submit to medical, surgical or other remedial treatment prescribed by her physician. These grounds also justified the apprehension and confinement under s. 49 or s. 57 of such persons, as did their refusal to submit to a medical examination to determine whether they were infected. The amended Act now provides that action under s. 49, s. 54 or s. 57 can

46. Re Insurance Act of Canada [1932] A.C. 41; A.G. Ont. v. Reciprocal Insurers [1924] A.C. 328; Citizens' Insurance Co. v. Parsons (1881) 7 App. Cas. 96.

47. Labatt Breweries, supra, note 39; Can. Federation of Agriculture v. A.G. Quebec [1951] A.C. 179.

48. Beaule v. Corp. of Master Electricians (1969) 10 D.L.R. (3d) 93; Re Underwood McLellan \& Assoc. Ltd. v. Sask. Assoc. of Professional Engineers (1979) 103 D.L.R. (3d) 268 (Sask C.A.).

49. E.g., Government of the Province of Alberta Personnel Policies and Procedures, Directive No: 12:14 "Acquired Immune Deficiency Syndrome (AIDS) In The Workplace".

50. "Government Strongly Considering Testing of All Immigrants for AIDS", Globe and Mail, (November 7, 1987) p. A1.

51. R.S.A., 1984 c. P-27.1, as am. These amendments were contained in Bill 36, the Public Health Amendment Act, 1988 which received Royal Assent on July 6, 1988.

52. "Doctors to Isolate Carriers of AIDS", Edmonton Journal, (May 12, 1988) p. A1.

53. Alberta Hansard (June 14, 1988) pp. 1742-1745; (June 21, 1988) p. 1891; (July 5, 1988) pp. 2215-2221. 
also be taken where the person refuses or neglects to "comply with any other conditions that ha[ve] been prescribed by a physician as being necessary to mitigate the disease or limit its spread to others". ${ }^{54}$ As there are no guidelines as to the content of such "conditions" these amendments confer considerable discretionary power on physicians.

These changes are problematic in several respects. First, it is not clear that they were needed given that, even without them, apprehension, confinement and quarantine orders were already much simpler to obtain in Alberta than in other provinces. Under the Public Health Act a compulsory examination and treatment certificate, which is authority for the apprehension and detention of a person for seven days, can be issued by the medical officer of health (M.O.H.) (s. 49(2)) or by a provincial court judge upon receipt of an information under oath by anyone who believes that an individual is violating any of the above requirements (s. 57). An isolation order can be issued by two physicians or by one physician supported by a laboratory report demonstrating the presence of an infectious agent (s. 54). While all the other provincial health statutes authorize the quarantine of individuals in certain circumstances these generally require: (i) that the process be initiated by a M.O.H.; and/or (ii) the involvement of the courts. ${ }^{\text {ss }}$

In the case of a seropositive person (SP) or a $\mathrm{PWA}^{\text {s6 }}$ there is the additional problem that the Public Health Act requires evidence from two physicians that the person detained under the isolation order is no longer infectious for an isolation order to be cancelled under s. 56(1) of the Act. As will be explained below, people are presumed to be permanently infectious from the point of HIV seroconversion onward. ${ }^{57}$ In Alberta, this could be a matter of particular concern as the Act does not contain any time limits for isolation orders. ${ }^{58}$

Another example of indirect legislative response, which could have a still greater impact on SPs and PWAs, is the recent amendments to the Health Act of British Columbia. ${ }^{99}$ Here again, while the amendments did not specifically address AIDS, their applicability to SPs and PWAs was a

54. Similar amendments have been made to s. 31(1) and s. 31(2) which outline the treatment obligations of persons who know, or have reason to believe, that they are or may be infected with a communicable or venereal disease.

55. E.g. the Health Act R.S.B.C. 1979, c. 161, as am. ss. 7, 69, 84 and 92; Health Protection and Promotion Act, 1983 S.O. 1983, c-10 as am., s. 35.

56. SPs and PWAs will be discussed separately because, as will be explained in Part III (a), infra, there is a range of HIV-related conditions and HIV seropositivity is distinct from AIDS.

57. This may have been a legislative oversight given that the definition of "isolation" in s. 1(1) was amended to eliminate the specification that isolation was "for the period of infectivity". N.B. A person may still apply to the Court of Queen's Bench for cancellation of an isolation order (s. 59).

58. The Health Protection and Promotion Act S.O. 1983, c-10, as am., s. 35(11) limits quarantine orders to four months at which time the M.O.H. must apply to the same court for an extension of the order, which also cannot exceed four months. N.B. s. 51(1) of the Public Health Act does prescribe seven days as the maximum period of confinement that can be imposed under a compulsory examination and treatment certificate issued pursuant to s. 49 or s. 57.

59. R.S.B.C. 1979 c. 161 , as am. These amendments were contained in Bill 34, the Health Statutes Amendment Act, which received Royal Assent on December 17, 1987. 
central theme of the debate on the amendments. ${ }^{60}$ However, the message from government officials was less clear. Although Health Minister Peter Dueck denied that the amendments would be used to quarantine PWAs, ${ }^{61}$ the changes were described by other government officials as being directed towards uncooperative SPs and PWAs. ${ }^{62}$

The chief effect of these amendments was to increase radically the powers of medical health officers (M.H.O.) over infectious individuals. ${ }^{63}$ Section 7(1), the most significant section in this regard, empowers a M.H.O. to order a person who has a communicable disease or is infected with "an agent" capable of spreading such disease to: (a) comply with conditions to prevent others from being exposed to the disease or agent; (b) to take or continue to take tests or treatment to identify or control the disease or agent; and/or (c) to place himself in some form of quarantine. ${ }^{64}$ In addition to this, s. 5(k) provides that the Lieutenant Governor in Council may make regulations governing the quarantine of people who have a communicable disease or "while susceptible to a reportable disease, ha[ve] been exposed to it".

The powers given to the M.H.O. under the amended Health Act are far broader than those under any analogous Canadian legislation. Most troubling with respect to SPs and PWAs are the provisions of s. 7(1)(b). How is the M.H.O. to determine whether a SP or a PWA is "likely" to expose others to HIV? Even if a SP or a PWA continued to be sexually

60. British Columbia Hansard (November 24, 1987) pp. 2635, 2637, 2639 and 2640; (November 25, 1987) pp. 2669-2675.

61. "Law to Quarantine Diseased May Discourage AIDS Tests", Victoria Times/Colonist, (July 9, 1987) p. A3.

62. This view was expressed by Dr. M. Rekart, Director of B.C's Centre for Sexually Transmitted Diseases and Dr. John Blatherwick, Vancouver medical health officer (M.H.O.): "Rights of the Reckless: B.C's Quarantine Bill Poses AIDS Dilemma", Globe and Mail, (July 18, 1987) p. D2; "New Quarantine Power Called Frightening to AIDS Sufferers", Vancouver Sun, (July 8, 1987) pp. Al-2.

63. Other amendments left the definition of a number of terms to be specified by the Lieutenant Governor in Council (s. 1), and provided for the gathering and dissemination of information for use in medical research (s. 5(1)). While the former is not particularly significant, the latter is a matter of concern with respect to information concerning SPs and PWAs. As amended, $s$. 5(1) does not provide adequate measures with respect to confidentiality nor does it adequately limit who can have access to such information.

64. R.S.B.C. 1979 c. 161 , as am., s. 7(1) provides as follows:

7.(1) Where a medical health officer has reasonable grounds to believe that

(a) a person has a reportable communicable disease or is infected with an agent that is capable of causing a reportable communicable disease, and (b) the person is likely to wilfully, carelessly or because of mental incompetence, expose others to the disease or the agent, he may order the person to do one or more of the following:

(c) to comply with reasonable conditions the medical officer considers desirable for preventing the exposure of other persons to the disease or the agent;

(d) to take or continue medical tests or treatment for the purpose of identifying or controlling the disease or agent;

(e) to place himself in isolation, modified isolation or quarantine as set out in the order. 
active he $e^{65}$ would not be "likely" to expose others to HIV unless he was engaging in high risk sexual practices. ${ }^{66}$ Thus, at best s. 7(1)(b) will not be used with respect to SPs or PWAs, as it imposes an impossible task on the M.H.O. At worst, s. 7(1)(b) will prove to be a license for the harassment of people who are, or are believed to be, members of a high risk group for HIV infection. Similar problems of overbreadth could arise with s. 5(k) unless "exposed" is interpreted strictly as meaning exposure to a known mode of transmission. ${ }^{67}$ Finally, the need for these amendments, like those to the Alberta Public Health Act, can be questioned, given the broad powers of quarantine that the M.H.O. already enjoyed under ss. 69,84 and 92.

Regulations dealing with AIDS-related issues have been enacted on both the federal and provincial level. Federally, since July 1987, SPs have been considered inadmissible for the purposes of s. 19(1) of the Immigration Act, $1976 .{ }^{68}$ However, this apparently will only affect those who volunteer the information that they are seropositive. Although s. 11 of the Immigration Act requires all immigrants and certain visitors to undergo medical examinations, the Canadian government has yet to implement compulsory HIV tests for such individuals. However, this policy may change as the Immigration Medical Review Board in September, 1987 reversed its previous position and recommended testing immigrants for HIV antibodies. ${ }^{69}$ In another federal development, the federal Correctional Service, while rejecting compulsory testing of prison inmates, has adopted an antiinfection policy under which guards handling seropositive inmates will be given protective clothing and disposable resuscitation equipment. ${ }^{70}$ The Correctional Service has also rejected the suggestion that condoms or sterile syringes be distributed to inmates to reduce the risk of HIV transmission in federal penitentiaries.

65. In this paper the masculine pronouns, he, his and him, will be used when referring to seropositive individuals or PWAs in the singular since the overwhelming majority of such persons are male.

66. Infra, pp. 507-508.

67. The modes of transmission are explained in Part IV(B) infra.

68. S.C. $1976-77$ c. 52 as am. s. 19(1) provides as follows:

19.(1) No person shall be granted admission if he is a member of any of the following classes:

(a) persons who are suffering from any disease, disorder, disability or other health impairment as a result of the nature, severity or probable duration of which, in the opinion of a medical of ficer concurred in by at least one other medical officer,

(i) they are or are likely to be a danger to public health or to public safety, or

(ii) their admission would cause or might reasonably be expected to cause excessive demands on health or social services.

The prohibition against the admission of SPs is found in s. 4.01.10 5(a) of the Medical Officer's Handbook. N.B. a positive ELISA result must be confirmed by a Western Blot test before the person seeking entrance can be excluded on this ground.

69. "Government Strongly Considering Testing of All Immigrants For AIDS", Globe and Mail, (November 7, 1876) p. A1; "Panel Urges Mandatory AIDS Testing of Immigrants", Globe and Mail, (September 4, 1987) p. A2.

70. "Prison Staff Get Anti-Infection Equipment", Globe and Mail, (August 15, 1987) p. A10. 
On the provincial level, all the provinces have amended regulations under their various public health statutes to require that cases of AIDS," AIDS and HIV seropositivity, ${ }^{2}$ or AIDS, AIDS-Related Complex (ARC) and HIV seropositivity ${ }^{73}$ be reported to public health authorities. In addition to the above, existing public health statutes contain many general provisions which could be applicable to PWAs. For example, public health authorities are commonly given broad powers such as the authority to enter and inspect premises and to compel a person suspected of having a transmissible disease to undergo a medical examination. ${ }^{74}$ Such statutes also impose various treatment obligations on such persons. ${ }^{75}$ Also, in Alberta, the Public Health Act authorizes the Director of Communicable Diseases to notify the sexual contacts of persons suffering from sexually transmitted diseases (STDs). ${ }^{76}$ Finally, various municipalities ${ }^{7}$ and school boards ${ }^{78}$ have adopted policies dealing with AIDS.

In the United States, there has been much more government activity than in Canada at both the policy and legislative levels. HIV testing is now mandatory for all applicants to the Job Corps, ${ }^{79}$ all recruits and active duty personnel in the Army, Air Force and Naval Services, ${ }^{80}$ all Foreign Service employees of the State Department, ${ }^{81}$ all inmates entering or leaving federal penitentiaries, ${ }^{82}$ and all applicants for immigrant visas. ${ }^{83}$ At the

71. Alberta, British Columbia, the Northwest Territories, Quebec and Yukon; MacKinnon and Krever, supra, note 7.

72. Manitoba, Nova Scotia, Ontario, Prince Edward Island and Saskatchewan; Id.

73. New Brunswick and Newfoundland; Id.

74. Public Health Act R.S.A. 1984, c. P-27.1, s. 40 (power to enter and inspect premises), s. 41 (mandatory examination); Health Act R.S.B.C. 1979, c. 161, as am., ss. 6 and 66 (power to enter and inspect premises), s. 7(c) and s. 70 (mandatory examination).

75. Section 31(1) of the Public Health Act R.S.A. 1984, c. P.27(1) as recently amended by Bill 36, supra, note 51 provides:

31(1) Every person who knows or has reason to believe that he is or may be infected with a communicable disease prescribed in the regulations for the purposes of this subsection shall immediately consult a physician to determine whether he is infected or not, and if he is found to be infected, shall submit to the treatment directed and comply with any other conditions prescribed by the physician until the physician is satisfied that he is not infectious.

Section 31 (2) contains an identical provision with respect to STDs. In addition to this s. 32 requires any such person to notify his physician, clinic, or the M.O.H. of the local board of health of any change in his address.

76. Public Health Act R.S.A. 1984, c. P-27.1, s. 66.

77. Policy and Guidelines with respect to AIDS For the Municipality of Metropolitan Toronto (November 1987); City of Vancouver Guidelines Re Persons With Aids Ref. No. 0161C.

78. Board Policies Manual Edmonton School District \#7, Policy HGAH; Policy Guideline \& Administrative Procedure Handbook, Edmonton Roman Catholic Separate School Board \#7, Policy 114, Guideline 114, Administrative Procedure 114.

79. APL 1:25 (Dec 31, 1986) p. 1.

80. APL 2:24 (December 16, 1987).

81. APL 2:1 (Jan. 28, 1987) p. 1.

82. $A U 2: 1(\mathrm{Jn} / \mathrm{Jl} 1987)$ p. 8.

83. Id. 
state and municipal levels mandatory HIV tests have been suggested or implemented for juvenile delinquents, ${ }^{84}$ prostitutes, ${ }^{85}$ persons convicted of drug or sex offences, ${ }^{86}$ inmates, ${ }^{87}$ persons diagnosed with other sexually transmitted diseases (STDs), ${ }^{88}$ applicants for marriage licenses, ${ }^{89}$ food service workers, ${ }^{90}$ students and teachers, ${ }^{91}$ hospital inpatients and mental patients $s^{92}$ and donors of blood, organs or semen. ${ }^{93}$ Statutes authorizing the quarantine of PWAs have been passed in several states, proposed in others and a number of SPs have actually been quarantined. ${ }^{94}$ Moreover, several states have implemented policies requiring notification of all sexual contacts, or spouses of persons determined to be seropositive.9s Other states have made it a criminal of fense to knowingly transmit HIV through the sharing of drug paraphernalia or sexual activity. ${ }^{\circ}$

On a somewhat brighter note, there have been legislative attempts to protect SPs and PWAs. Bills prohibiting discrimination on the basis of AIDS, HR3071 and S1575, have been introduced in the Congress ${ }^{97}$ and such discrimination has also been prohibited in several cities. ${ }^{98}$ Finally, New York, California and the District of Columbia have made it illegal for insurance companies to require HIV tests from applicants for health or life insurance. ${ }^{99}$

84. Georgia HB1281: APL 3:3 (Feb 24, 1988) p. 4.

85. Calif. AB 2319: $A U$ 2:6 (March, 1988) p. 7; Georgia: $A U$ 2:1 (Jn/Jl 1987) p. 6; Nevada Law AB550: $A P L$ 2:19 (Oct 7, 1987) p. 8; North Dakota: $A P L$ 2:24 (Dec 16, 1987) p. 6; Newark N.J.: $A U 2: 5$ (Feb 1988) p. 1.

86. Illinois H.B. 2044: $A U$ 2:4 (Nov 1987) p. 5; Calif. SB 1007: $A U$ 2:6 (March, 1988) p. 7.

87. Calif. SB 1005: $A U$ 2:6 (March, 1988) p. 7; Georgia HB1281: APL 3:3 (Feb 24, 1988) pp. 4-5.

88. North Dakota: $A P L$ 2:24 (Dec 16, 1987) p. 6.

89. Illinois H.B. 2044: $A U$ 2:4 (Nov 1987) p. 5; New Hampshire HB322: $A P L$ 2:9 (May 20, 1987) p. 9; North Dakota: $A P L$ 2:24 (Dec 16, 1987) p. 6.

90. Georgia HB1281: $A P L$ 3:3 (Feb 24, 1988) p. 4.

91. Georgia: $A U 2: 1(\mathrm{Jn} / \mathrm{Jl} 1987)$ p. 6.

92. Calif. SB 1006: AU 2:4 (November, 1987) p. 5; Georgia HB 1281: APL 3:3 (Feb 24, 1988) p. 4.

93. Michigan HB 4980: $A U 2$ 2:6 (March, 1988) p. 8; North Dakota: $A P L 2: 24$ (Dec 16, 1987) p. 6.

94. Colorado HB117: APL 2:11 (June 17, 1987) p. 1; Florida: APL 3:2 (Feb 10, 1988) p. 3; Illinois SB 651: $A U$ 2:2 (Aug 1987) p. 6; Louisiana HB1041: APL 2:12 (July 1, 1987) p. 8; Minnesota SF 1048: AU 2:2 (Aug, 1987); Washington HB6621: AP\&L 3:1 (Jan 27, 1988) p. 6. Seropositive prostitutes have been quarantined in California, Illinois, Mississippi, and Nevada. In Florida a judge ordered a 14 year old seropositive boy quarantined although a week later he rescinded his order. For an overview of the history of quarantine see W. Parmet, "AIDS and Quarantine: The Revival of an Archaic Doctrine" (1985) 14 Hofstra L. Rev. 53 at 55-71; See also R. Elsberry, “AIDS Quarantine in England and the United States" (1986) 10 Hastings Int. \& Comp L. Rev. 113.

95. Illinois S.B. 651: $A U 2: 4$ (Nov 1987) p. 5.

96. Supra, notes 92 and 93.

97. APL 2:15 (Aug 12, 1987) p. 1.

98. Such legislation has been enacted in; Austin, Texas, Los Angeles, San Francisco, West Hollywood and Hayward, Calif: APL 1:25 (Dec 31, 1986) p. 1; Santa Clara County, Calif.: $A P L$ 2:24 (Dec 26, 1987) p. 3; Sacramento Calif.: $A P L$ 2:9 (May 20, 1987) p. 3; and Riverside, Calif.: $L / G L N 11$ (Feb 1988).

99. $A U 2: 6$ (March 1988) p. 5. 


\section{B. CASE LAW}

In Canada, a variety of AIDS-related cases have arisen. While most are still not resolved some have been settled and three have resulted in decisions. ${ }^{100}$ In the United States, there has been an explosion of AIDSrelated litigation. If one includes such actions as human rights complaints, labour grievances, etc., hundreds, if not thousands, of cases are currently in progress. These cases have occurred primarily in the areas of (i) labour law; (ii) anti-discrimination law; (iii) criminal law; (iv) torts; and (v) family law. These developments are important for two reasons. First, these cases suggest a range of AIDS-related legal issues that are likely to arise in Canada. Second, and more important for our purposes, an analysis of these cases indicates what medical issues consistently have proven to be critical to the resolution of AIDS-related legal problems.

\section{Labour Law}

Both the Canadian and American experiences to date suggest that labour law will generate more AIDS-related cases than other areas of law. In Canada, some employers already have indicated their intention to implement mandatory HIV tests and to dismiss seropositive employees. ${ }^{101}$ So far, two of the three Canadian decisions dealing with AIDS have been labour arbitrations ${ }^{102}$ and several suits for wrongful dismissal involving AIDS have been initiated. ${ }^{103}$ In the United States there have been hundreds of employment-related cases. People who were, or were thought to be, seropositive have been refused employment, ${ }^{104}$ transferred ${ }^{105}$ or had their duties modified, formally or informally, in order to reduce or eliminate contact with others, ${ }^{106}$ demoted, ${ }^{107}$ placed on medical leave, ${ }^{108}$ laid off,${ }^{109}$

100. Re Pacific Western Airlines and Canadian Air Line Flight Attendants Association (1987) 28 L.A.C. (3d) 291; Walton v. Treasury Board of Canada (Correctional Service Canada), unreported, 23 June, 1987, Public Service Staff Relations Board, 165-2-21; R. v. G.D.M., unreported, 3 February 1988, Vancouver Registry No. CC871598 (Van. Co. Ct.).

101. Ridley College in St. Catharines, Ont. purportedly is moving towards implementing such a policy and it has been considered at other private schools: "Private Schools Drafting AIDS Plans", Globe and Mail. (November 4, 1987) p. A7.

102. Re Pacific Western Airlines, supra, note 100; Walton v. Treasury Board of Canada (Correctional Services Canada), supra, note 100.

103. E.g., Campbell v. Schill and Mac's Convenience Stores S.C.O. No. 17314/87; DeFrederico v. Southam Communications Ltd. S.C.O. No. 307280/87.

104. Doe v. Westchester County Medical Center N.Y. SDHR Case No. 1B-P-D-87-117683, APL 2:22 (November 18, 1987) p. 2.

105. Doe v. New York Hospital No. GA-00035041487-DN, N.Y.C. Commission of H.R.

106. In OHRC Case 30-616D the complainant, a male homosexual, alleged that delay in permitting him to perform the $\mathbf{5 0}$ contact lens fittings required for his professional accreditation was due to a concern that he might have AIDS. See also Chalk v. Orange County Superintendent of Schools (U.S.C.A. 9th Cir. 1987) No. 87-6418 D.C. No. CV 8710569 WPG; Rice v. Bloomer No. 87-162-A, E.D. Va.

107. Wolfe v. Tidewater Pizza Inc. No. C87-662, Cir. Ct., Norfolk Va., AU 2:3 (Oct 1987) p. 4.

108. United Airlines v. Association of Flight Attendants AFA Case 64-12-2-270-83.

109. Raytheon Co. v. FEHC, Calif Super Ct., Santa Barbara Cty, No. 167995; Laredo v. Southwest Community Health Services, Inc. CIV 86-1313 (U.S. Dist. Ct., Dist. of N.M., October 29, 1986). 
suspended with ${ }^{110}$ or without ${ }^{111}$ salary, and fired. ${ }^{112}$ In other cases, a negative result on an HIV antibody test has been made a condition for continued employment ${ }^{113}$ or reinstatement. ${ }^{114}$

In virtually all of these cases the employers have justified their acts on the grounds that a seropositive employee might transmit HIV to coworkers or customers. However, two other justifications have also been advanced: (i) that a seropositive employee's condition renders him incapable of performing his duties; ${ }^{115}$ and/or (ii) that a seropositive employee might endanger his own health by continuing to work. ${ }^{116}$ The usual response to such acts by the employer has been to grieve if there is a collective agreement, to lodge a handicap discrimination claim under the appropriate human rights legislation, ${ }^{117}$ or to sue for wrongful dismissal.

But the legal issues are not confined to the aggrieved employee. Both the employer and other employees have certain rights and duties, at common law, under arbitral jurisprudence and pursuant to statute, that may be implicated in AIDS-related situations. For example, the employer has a right to have his employees perform those services contemplated by the employment contract in a consistent and adequate fashion. Thus, where an employee is suffering from an illness or disability which renders her incapable of performing the tasks expected of her or which prevents her from reporting to work regularly, she can be demoted, transferred, laid off, placed on a medical leave of absence or terminated.$^{118}$ This suggests that, in certain circumstances, an employee whose AIDS-related disorder has affected his capacity to discharge his employment duties may be fired,

110. Re Pacific Western Airlines, supra, note 100.

111. OHRC Case 71-638G.

112. Lentz v. Toronto Western Hospital OHRC Case 60-951A; OHRC Case 80-540G; OHRC Case 60-604G; OHRC Case 76-761A; OHRC Case 60-704A; OHRC 60-990A; Campbell, supra, note 103; DeFrederico, supra, note 103; Shuttleworth v. Broward County 639 F. Supp. 654 (S.D. Fla. 1986); Cronan v. New England Telephone Co. 41 F.E.P. Cases 1273; Leckelt v. Terrebonne Hospital No. 86-4235, (U.S.D.C., E.D. Louisiana 1986); Brunner v. Al Attar (Texas Dist. Ct., Harris County 1986) ACLU 15; Dept. of Health and Human Services v. Charlotte Memorial Hospital Complaint No. 04-84-3096 (Office for Civil Rights, Region Iv, HHS Aug 5, 1986); Re Nursing Home and Union 88 LA 681 1987; Doe v. Sinacola No. 86-320825NZ (Civ. Ct., Oakland Co. 1986); Little v. Bryce 44 Emp. Prac. Dec. (CCH) 37,330 (Texas Ct. of Appeal 1987).

113. Peterson v. Sperry, APL 2:5 (March 25, 1987); Leckelt, supra, note 112.

114. Charlotte Memorial Hospital, supra, note 112; Wolfe, supra note 107.

115. In Pacific Western Airlines, supra, note 100, the employer argued that various HIV-related disorders could affect the physical capacity of the grievor, a flight attendant, to discharge all his duties. A similar argument was made in United Airlines, supra, note 108.

116. In United Airlines, supra, note 108, the employer informed the grievor that a medical leave of absence was advisable because "it was in the best interest of your short and long term health not to expose your immune system to the multitudinous variety of viruses and bacteria that are abundant in the ambient air of an airline cabin"'

117. The mechanics of employment discrimination claims will be discussed in the next section. They are mentioned here simply to illustrate the range of possible employee responses to such employer actions.

118. At common law, a permanent disability which prevents an employee from working is cause for discharge: Dartmouth Ferry Commission v. Marks (1903) 34 S.C.R. 366 (S.C.C.); Layne v. Pullman Co. and Deyell [1955] O.W.N. 219 (H.C.J.). The arbitral jurisprudence supporting the same proposition can be found in Brown and Beatty, Canadian Labour Arbitration (2d ed.) at 7:3200 and 7:3220. 
etc. Indeed, in Pacific Western Airlines the arbitrator noted that in such circumstances the "employer would be free to respond to the deterioration of an employee with AIDS that affected the employee's performance"."19

Employers also have a duty at common law to provide a safe place of employment. ${ }^{120}$ This duty has also been recognized in the arbitral jurisprudence and in certain labour legislation, such as the Occupational Health and Safety Act. ${ }^{121}$ Employees have a corresponding right to refuse dangerous work. This right could be invoked in at least two AIDS-related situations. The first is that in which employees are required to deal with body fluids which might contain HIV. A recent example involved inside postal workers who complained that blood samples, including samples of blood collected for HIV testing, were being mailed in Canada without being placed in secure containers. ${ }^{122}$ The second situation is that in which the employee's responsibilities bring her into contact with HIV positive individuals. This contact could be either of an intimate nature, such as that which presents itself in many medical contexts, or of a casual nature, such as that involved in sharing an office with, or waiting on, an HIV positive individual. The cases indicate that even in casual contact situations coworkers and customers can become very disturbed about the prospect of working beside or being served by a seropositive individual. This is demonstrated by Pacific Western Airlines where the grievor, an airline steward, was only suspended after a pilot expressed concerns about working with him. Moreover, there is anecdotal evidence which suggests that some air travellers supported the airline's decision to suspend the grievor. ${ }^{123}$

It is striking to note how many of the labour cases have involved health care workers, school personnel and food service employees. This prevalence not only indicates what are generally perceived (often incorrectly) to be possible routes for HIV transmission, but also raises the question of whether there are any jobs which legitimately should be restricted to seronegative employees.

\section{Anti-discrimination Statutes}

There are anti-discrimination statutes in all of the provinces and both territories. ${ }^{124}$ These statutes all have the same essential format, prohibiting

119. Pacific Western Airlines, supra, note 100, p. 302.

120. Marshment v. Borgstrom [1942] S.C.R. 375 (S.C.C.).

121. R.S.A. 1980 c. O-2 s. 2. See also the Canada Labour Code Part IV, R.S.C. 1970, c. L-1.

122. "Rules on Blood Ignored, Postal Union Says", Globe and Mail, (October 31, 1987) p. A14.

123. "Airline's Grounding of Man With AIDS Gets Mixed Reaction", Globe and Mail, (April 20, 1987) p. A13.

124. Canada Human Rights Act S.C. 1976-77, c. 33 as am.; Alberta Individual's Rights Protection Act R.S.A. 1980, c. I-2, as am.; British Columbia Human Rights Act S.B.C., c. 22 as am.; Manitoba Human Rights Act S.M. 1974, c. 65, as am.; New Brunswick Human Rights Code R.S.N.B. 1973, c. H-11, as am.; Newfoundland Human Rights Code R.S.N. 1970, c. 262, as am.; Human Rights Act S.N.S. 1969, c. 11, as am. (Nova Scotia); Ontario Human Rights Code 1981 S.O. 1981, c. 53, as am.; Prince Edward Island Human Rights Act S.P.E.I. 1975, c. 72, as am.; Charter of Human Rights and Freedoms 1975, c. 6 (Quebec); The Saskatchewan Human Rights Code, R.S.S. 1978, c. S-24.1; Northwest Territories Fair Practices Act R.S.N.W.T. 1974, c-F2, as am.; and Yukon Territory Human Rights Act S.Y. 1987, c. 3. 
discrimination on a number of specified grounds ${ }^{125}$ in particular spheres of activity. ${ }^{126}$ The American experience graphically indicates that AIDSrelated discrimination can, and is likely to, occur in any of these spheres. ${ }^{127}$ For example, as demonstrated above, instances of employment discrimination have been common. Complaints of discrimination in the provision of services have been made against dentists, ${ }^{128}$ morticians, ${ }^{129}$ nursing homes ${ }^{130}$ and drug and alcohol rehabilitation programs. ${ }^{131}$ Discrimination in accommodation and in contract also have occurred with respect to both leasehold, and purchase and sale agreements. ${ }^{132}$

In Alberta, the Human Rights Commission has received three complaints involving AIDS, involving employment, tenancy and public accommodation respectively. ${ }^{133}$ In Ontario, the Human Rights Commission has received fifteen AIDS-related complaints to date: the eight employment-related cases mentioned above; ${ }^{134}$ six relating to services and one involving contracts. The services complaints involved dental care, ${ }^{135}$ hospital care, ${ }^{136}$ the provision of social assistance, ${ }^{137}$ insurance, ${ }^{138}$ and service in a restaurant. ${ }^{139}$ The contract complaint involved the refusal of a landlord to rent space to an AIDS support group. ${ }^{140}$ On the federal level, the Canadian Human Rights Commission has received three AIDS-related complaints. ${ }^{141}$

It seems likely that complaints in AIDS-related cases will be dealt with as discrimination on the basis of "handicap" or "physical disability" which is

125. E.g., the Ontario Human Rights Code prohibits discrimination on the basis of race, ancestry, place of origin, colour, ethnic origin, citizenship, creed, sex, sexual orientation, age, marital status, family status or handicap.

126. E.g., the Ontario Human Rights Code prohibits discrimination in services, accommodation, contracts, employment, and vocational associations.

127. A good survey of the various types of AIDS-related discrimination is contained in the report of the New York City Commission on Human Rights' AIDS Discrimination Unit, Report of Discrimination Against People With AIDS and People Perceived to Have AIDS.

128. Campanella v. Hurwitz D.D.S. No. GA-00021030487-D (N.Y.C. H.R. Comm); Whittacre and Whitmore v. Northern Dispensary AU-00015021387 and GA-00023030687 (N.Y.C. H.R. Comm).

129. DiMiceli v. N. Y.C. Commission on Human Rights Complaint No. 0306 2686-CI.

130. McEnany v. Four Seasons Nursing Center No. 409241 (Dist. Ct., Travis County, Tex. 1986) (A man with ARC was refused admission to a nursing home).

131. Caselv. Milam Recovery Center King Cty Sup Ct. Cause No. 82-2-16852-4; Doe v. Centinela Hospital No. CV 8702514 (U.S. Dist. Ct., C.D. Cal.).

132. Seitzman v. Hudson River Associates ACLU 109; Wolf v. Barton No. 049486. (N.Y.C.H.R. Comm); Poff v. Caro No. L-28516-87 (Superior Ct. of N.J., Hudson Cty 1987).

133. Personal communication with Carol Wodak, Director, Northern Region Office, Alberta Human Rights Commission - July 8, 1988.

134. Supra, notes 106,111 and 112 .

135. OHRC Case 76-562A.

136. OHRC Case 30-614D.

137. OHRC Case 76-547A.

138. OHRC Case 10-778C; OHRC Case 10-779C.

139. OHRC 50-690B.

140. OHRC Case 60-849A.

141. Canadian Human Rights Commission, Annual Report 1987 (March 1988) p. 25. 
a prohibited ground in all the Canadian human rights statutes. ${ }^{142}$ Indeed, while there has yet to be a decision on this point, this is the official policy of the Ontario Human Rights Commission ${ }^{143}$ and both the Alberta and Canadian Human Rights Commissions are currently processing such claims as discrimination on the basis of disability.

It is important to recall that there are two elements in a successful complaint of handicap discrimination. The complainant must have been discriminated against because of a handicap and be otherwise capable of exercising the right in question.

In order to meet the first of these two requirements AIDS must constitute a handicap. There are several minor differences between the definitions of handicap or physical disability contained in the various Canadian human rights statutes. ${ }^{14}$ The definition in the Ontario Human Rights Code is the broadest and provides as follows: ${ }^{145}$

9 (1)(b) "because of handicap" means for the reason that the person has or has had, or is believed to have or have had,

(i) any degree of physical disability, infirmity, malformation or disfigurement that is caused by bodily injury, birth defect or illness and, without limiting the generality of the foregoing, including diabetes mellitus, epilepsy, any degree of paralysis, amputation, lack of physical coordination, blindness or visual impediment, muteness or speech impediment, or physical reliance on a dog guide or on a wheelchair or other remedial appliance or device,

(ii) a condition of mental retardation or impairment,

(iii) a learning disability or a dysfunction in one or more of the processes involved in understanding or using symbols or spoken language,

(iv) a mental disorder, or

(v) an injury or disability for which benefits were claimed or received under the Workers'

Compensation Act.

The fact that there is a broad spectrum of AIDS-related conditions ${ }^{145}$ must be kept in mind when discussing whether AIDS fits within a particular definition of handicap or physical disability. It seems clear that anyone suffering from any of the disabling effects of AIDS or an AIDSrelated condition would be covered by these definitions. However, it might be argued that an asymptomatic, seropositive individual is not caught by such language. While such a person would be presumed to be contagious, it could be argued that until he develops symptoms he could not be said to be suffering "any degree of physical disability".

142. It might also be possible to claim that such AIDS-related actions constitute discrimination on the basis of sex (prohibited in all the provinces) or sexual orientation (prohibited in Manitoba, Ontario, Quebec and the Yukon) insofar as they have a disparate impact on men or homosexuals respectively. However, it would be much more straightforward to treat these cases as instances of handicap discrimination.

143. Ontario Human Rights Commission, Annual Report 1985-86 p. 33. In Lentz, supra, note 112, a Board of Inquiry was appointed, however, the case was settled.

144. The Alberta Individual Rights Protection Act and all of the other Human Rights Statutes (except those in B.C. and the Northwest Territories), provide a definition of physical disability or handicap similar to that contained in s. $9(1)(b)(i)$ of the Ontario Act. Only Ontario specifically covers perceived disability, and all the others, except for the Canada Human Rights Act and the P.E.I. Human Rights Act speak of the handicap in the present tense.

145. S.O. 1981, c. 53 , as am.

146. Infra, Part IV (C). 
This point had provoked considerable controversy in the United States with respect to the applicability of the Rehabilitation Act of 1973, the major Federal disability discrimination statute, to AIDS and AIDS-related conditions. In a memorandum released in June, 1986, the Cooper Memorandum, the United States Department of Justice offered the following analysis of the applicability of the Rehabilitation Act to AIDS..$^{147}$ They suggested that the disabling effects of AIDS are clearly handicaps within the meaning of the statute. However, they argued that asymptomatic seropositivity, even though accompanied by a presumption of contagiousness, does not constitute a handicap. In their view an asymptomatic seropositive individual "does not have a physical or mental impairment, 'because (his) condition - the presence inside his body of the active infectious agent - has no adverse physical consequences for him'”' ${ }^{48}$ This analysis was widely criticized by commentators ${ }^{149}$ and apparently has been rejected by the courts which have held that asymptomatic SP's ${ }^{150}$ as well as symptomatic PWAs ${ }^{131}$ are entitled to claim the protection of the Rehabilitation Act.

The second requirement of a successful handicap discrimination claim, that a handicapped individual be otherwise capable of exercising the right in question, will be very important, particularly in the employment context. This issue could be raised in an AIDS-related handicap discrimination claim in two ways. First, it must be determined whether or not the physical effects of the AIDS-related condition on the individual in fact make it impossible for him to exercise the right. This is a relatively straightforward question which can be determined on the basis of medical evidence. The more contentious point will be whether or not the presumptive contagiousness of a seropositive individual, without more, renders him incapable of exercising the right. The Cooper Memorandum suggested that the contagiousness of seropositive individuals renders them not "otherwise qualified" under the Rehabilitation Act. However, in School

147. Memorandum from Assistant Attorney General Cooper on Application of Section 504 of the Rehabilitation Act to Persons with AIDS, reported in [May-June] Daily Lab. Rep. (BNA) No. 122, D-1, p. D-8 (June 25, 1986).

148. Id., at $\mathrm{D}-8$.

149. J.H. Carey and M.A. Arthur, "The Developing Law On AIDS In The Workplace" (1987) 46 Maryland L.R. 284; P.A. Curylo, "Note: AIDS and Employment Discrimination: Should AIDS Be Considered A Handicap?" (1987) 33 The Wayne L.R. 1095; A.S. Leonard, "AIDS in the Workplace" in A\&L I supra, note 8, 109; R.P. Wasson Jr., "AIDS Discrimination Under Federal, State, and Local Law after Arline" (1987) 15 Fla St. L.R. 221; J.E. Broadus, "Arline: The Application of the Rehabilitation Act of 1973 to Communicable Diseases" (1988) 39 Labour L.J. 273; "AIDS According to the Justice Department" (1986-87) 12 Employee Rel. L.J. S15; Note, “Asymptomatic Infection with the AIDS Virus as a Handicap Under the Rehabilitation Act of 1973" (1988) 88 Col. L. Rev. 563.

150. Thomas v. Atascadero Unified School District 662 F. Supp 376 (C.D. Cal. 1987); Local 1812, American Federation of Government Employees v. United States Department of State $662 \mathrm{~F}$. Supp. 50 (D.D.C. 1987); District 27 Community School Board v. Board of Education of the City of New York 130 Misc 2d 398 (Sup. Ct. 1986); Doe v. Belleville Public School District No. 118 DC S 111, Civil No. 87-3836.

151. Chalk, supra, n. 106. 
Board of Nassau County, Florida v. Arline, ${ }^{152}$ a case involving a woman with tuberculosis, the United States Supreme Court accepted the argument that discrimination on the basis of contagiousness could constitute discrimination on the basis of handicap. The Court stressed that differential treatment on the basis of contagiousness alone would require solid medical justification. Moreover, in Thomas a seropositive student was found to be "otherwise qualified" to attend regular kindergarten classes, ${ }^{153}$ and in Chalk a teacher with AIDS was found to be "otherwise qualified" for classroom duties. ${ }^{154}$

Finally, it should be noted that the determination of whether a handicapped individual is otherwise capable of exercising the right involves a consideration of whether or not the individual's special needs, if any, can be reasonably accommodated. In the context of AIDS, accommodation might involve such things as permitting flexible work hours to permit attendance for medical care.

\section{Criminal Law}

The issue likely to be most important in the realm of criminal law is the appropriateness of attaching criminal liability to the knowing transmission, or attempted transmission, of HIV. Criminal sanctions could be imposed by either creating a new AIDS-specific offence or by applying existing offences. The creation of an AIDS-specific offence would not be without precedent in Canada. Under former s. 253(1) of the Criminal Code it was a summary offence for a person to knowingly communicate a venereal disease to another. ${ }^{155}$ However, this section fell out of use and was repealed in $1985 .{ }^{136}$ In the United States offences related specifically to

152. $107 \mathrm{~S}$. Ct. 1123 (1987). While the majority opinion, in footnote 7, explicitly left open the question of whether or not a person with AIDS should be considered handicapped under the Rehabilitation Act, their language in the rest of the opinion suggests that they would answer this question in the affirmative.

153. Supra, note 150.

154. Supra, note 106.

155. 253.(1) Every one, who, having venereal disease in a communicable form, communicates it to another person is guilty of an offence punishable on summary conviction.

(2) No person shall be convicted of an of fence under this section where he proves that he had reasonable grounds to believe and did believe that he did not have venereal disease in a communicable form at the time the offence is alleged to have been committed.

(3) No person shall be convicted of an offence under this section upon the evidence of only one witness, unless the evidence of that witness is corroborated in a material particular by evidence that implicates the accused.

(4) for the purposes of this section, "venereal disease" means syphillis, gonorrhea or soft chancre.

1953-54, c. 51, s. 239.

156. Section 253(1) was repealed by the Criminal Law Amendment Act S.C. 1985, c. 19, s. 42. The last prosecution for this offence was under s. 316A, the predecessor of s. 253(1), in 1922; MacKinnon and Krever, supra, note 7. 
AIDS have been enacted in some states ${ }^{157}$ and proposed in others. ${ }^{158}$ The CBAO Report argued that such an offence was unnecessary as adequate protection against the irresponsible carrier already exists under provincial public health statutes. ${ }^{139}$ The Report also suggested that a criminal sanction would be superfluous in that it likely would not be an effective deterrent. Nonetheless, the Federal Department of Justice is studying the question. ${ }^{160}$

In Canada, to date there have been only two criminal cases directly involving AIDS. ${ }^{161}$ The only decision has been in R. v. G.D.M., ${ }^{162}$ a sentence appeal by a young offender convicted of soliciting under s. 195.1(c) of the Criminal Code. In this case the Court considered the propriety of a probation order requiring the young offender to furnish his youth worker, once a month, for the six month term of his probation, with a medical certificate stating that he had been "examined for AIDS and other venereal diseases within that previous month". Judge Ryan agreed that "if the sole reason for the imposition of this condition were for the protection of the public health rather than for the deterrence of the offender then the order would not be justified". ${ }^{163}$ But he upheld the ordering of an AIDS test in this case as being "a condition which tends to promote the good conduct of the offender ... and to prevent the commission of further offences".$^{164}$ In his view an HIV test would have this effect as it would "bring home to the young person the dangers inherent in the occupation he has chosen" and would demonstrate that "he is a member of a high risk group of individuals and to continue this way of life may mean exposure to a deadly disease whether he utilizes 'safe' practices or not."'6s However, Ryan C.C.J. concluded that ordering six HIV tests was excessive and allowed the appeal to the extent that the probation order was amended to require only one HIV test during the term of probation.

157. E.g., Florida St 384 makes it a second degree misdemeanor for a seropositive person to have sex with someone else: $A P L$ 3:2 (Feb 10, 1988) p. 2; Louisiana Act 663 makes "sexual contact without the knowing and lawful consent of the victim" a crime punishable by a sentence of up to 10 years imprisonment or a fine of up to \$5000: $A U 2: 2$ (Aug, 1987) p. 7 .

158. E.g., In California SB 1002 makes it a felony punishable by a sentence of 2 to 6 years for a person who, knowing they are seropositive, donates blood; SB 1004 mandates a three year sentence enhancement for anyone who, knowing they are seropositive, commits and is convicted of a sexual of fence: $A U 2: 4$ (Nov 1987) p. 5; Florida HB 236 makes it a third degree felony for prostitutes to have sex after they have found out about their infection punishable by 1 to 5 years imprisonment and a fine of up to $\$ 5000: A P L$ 3:2 (Feb 10, 1988) p. 2. Georgia HB1281 creates the offences of "AIDS battery" - HIV transmission through sex or needle sharing, and "aggravated AIDS battery" - HIV transmission resulting from rape, sodomy, or adultery. The former offence is punishable by a sentence of 1 to 5 years, while the latter provides for a sentence of 29 to 39 years: $A P L$ 2:11 (June 17, 1987) p. 7 or $A P L$ 3:2 (Feb 10, 1988).

159. Supra, note 7, p. 61.

160. Supra, note 7, pp. 60-61.

161. AIDS was raised in another case where the defendant, who pleaded guilty to fraud, explained that he had stolen $\$ 10,000$ from his employer to have "a final fling" after he had discovered that he was seropositive: "AIDS Test Sparked Theft, Law Clerk Gets Jail Term", Globe and Mail, (July 10, 1987) p. A11.

162. Supra, note 100.

163. Id., p. 8.

164. Id., p. 7.

165. Id., pp. 7-8. 
In G.D.M. the appellant also raised what is likely to be the chief constitutional challenge to any scheme of mandatory HIV testing, i.e., that the taking of the requisite blood sample constitutes an unreasonable search and seizure under s. 8 of the Canadian Charter of Rights and Freedoms. ${ }^{165}$ Relying on Pohoretsky v. The Queen, ${ }^{167}$ Judge Ryan accepted that the taking of blood may constitute a search or seizure for the purposes of s. 8 . He stated that such a search could not be unreasonable if "it relates to securing the good conduct of the offender". ${ }^{168}$ Thus, in his view, the s. 8 issue could be resolved in the context of determining the fitness of the sentence. The end result then, would appear to be that while ordering six HIV tests in this case would violate s. 8 of the Charter, ordering one HIV test would not.

In the second Canadian case, $R$. v. Thornton, a seropositive man was charged with common nuisance (s. 176) after he donated blood to the Red Cross while he was aware of his HIV antibody status. ${ }^{169}$ The accused said he did so in the mistaken belief that his body would replace the donated blood with blood uninfected by HIV. He also claimed that he was confident that the blood he had donated would be detected and rejected by the screening process used by the Red Cross.

Perhaps the most disturbing aspect about this case was the way it was handled by the police. Shortly after Mr. Thornton was charged, Supt. J. McCombie, head of the Ottawa Police Department's criminal investigation branch, held a news conference during which he released a photograph of Mr. Thornton and alleged that he was continuing to spread HIV through continued sexual activity. The story and photograph were widely reported in the Canadian print media. ${ }^{170} \mathrm{As}$ a result, $\mathrm{Mr}$. Thornton is suing Supt. McCombie for invasion of privacy. ${ }^{171}$

In the United States there have been a number of cases involving sexual acts, in which the possibility of HIV transmission either constituted the offence itself or caused the elevation of the offence charged. In People v. Sherouse 172 a prostitute was charged with two counts of attempted manslaughter for having sex with customers after finding out that she was HIV seropositive. In People v. Hawkrigg ${ }^{173}$ a judge sustained the indictment, on charges of reckless endangerment, of a man who allegedly had sex with an underage boy. In State v. Phillips ${ }^{174}$ the defendant was initially

166. As enacted in Canada Act 1982 (U.K.), c. 11.

167. (1987) 33 C.C.C. (3d) 398 (S.C.C.).

168. R. v. G.D.M., supra, note 100.

169. Ottawa Registry File No. 157SCO. As of July 11, 1988 the preliminary inquiry in this case had not yet been completed.

170. "AIDS-Carrier Charged Over Blood Donation", Globe and Mail (March 17, 1988) p. A10; "Use Of Blood Donor's Photo Assailed", Globe and Mail (March 18, 1988) p. A12.

171. "Tainted Blood Suspect To Sue Police", Edmonton Journal, (July 12, 1988) p. A2. In his statement of claim Mr. Thornton claims that, subsequent to the police press conference, he received threatening phone calls, suffered power cuts to his home and was expelled from several clubs. He also claims that this resulted in strained relations with his family.

172. Fla. Case No. OCSCO 87-185679; AU 2:6 (March 1988) p. 2. Interestingly these charges were laid despite the fact that the clients involved wore condoms during the sexual encounter.

173. NYLJ (Feb 17, 1988) p. 28, col. 7.

174. S.C. Case No. B-87-4841, B-87-4886, B-87-5613. Charges were eventually dropped after the complainant refused to return to South Carolina to testify. $A P L$ 2:19 (Oct 7, 1987) p. 6. 
arrested for assault and criminal sexual conduct (rape). After it was confirmed that the defendant was HIV positive he was indicted for criminal sexual conduct and for assault and battery with intent to kill by "intentional exposure to AIDS during sexual conduct".

The risk of HIV transmission has had a similar impact in cases involving non-sexual contact. In Florida v. Dunn, ${ }^{175}$ two inmates were charged with conspiracy to commit first degree murder after they spiked a guard's coffee with HIV positive serum. In Indiana $v$. Haines ${ }^{176}$ a man with AIDS-Related Complex (ARC) who, after slashing his wrists, had thrown blood on a policeman and two paramedics, was found guilty of three counts of attempted murder. In U.S. v. Moore ${ }^{177}$ a seropositive inmate who bit two guards during a scuffle was found guilty of assault with a dangerous weapon.

The majority of the American cases involve charges under existing offences which are not directed specifically at AIDS. This was also done in $R$. v. Thornton. If this becomes the general approach to such cases in Canada there are a number of other offences which might be found applicable. Part IV of the Criminal Code, Offences against the Person and Reputation, contains a number of offences which could theoretically be used to criminalize HIV transmission, whether through sexual activity or otherwise. If the transmission resulted in the death of the person infected, the person responsible for the HIV transmission (the transmitter) might be charged with causing death by criminal negligence (s. 203), manslaughter (s. 217) ${ }^{178}$ or perhaps even first or second degree murder (s. 214). ${ }^{179}$ If the transmission did not result in death, the transmitter might be charged with causing bodily harm by criminal negligence (s. 204), unlawfully causing bodily harm (s. 245.3), administering a noxious thing (s. 229), or attempted murder (s. 222). ${ }^{180}$

The presence of HIV transmission might also influence the particular variant of the of fence charged. For example, if HIV transmission resulted from a sexual assault the transmitter might be charged with sexual assault with a weapon (s. 246.2), or aggravated sexual assault (s. 246.3) rather than mere sexual assault (s. 246.1). Finally, HIV transmission might be a consideration in sentencing for such offences as assault, sexual assault, the Part IV sexual offences, etc.

175. Union Cty Cir Ct, No. 86-66CF; APL 2:19 (Oct 7, 1987) p. 5.

176. Tippecanoe (Ind) Super Ct, No. S-5585; APL 3:2 (Feb 10, 1988) p. 4.

177. USDC DMinn, No. Crim 4-87-44; The defendant is facing up to 10 years imprisonment and/ or a fine up to $\$ 250,000$. Biting was also involved in the case of Barlow v. Superior Ct. Calif. Ct. of Appeals, 4th Dist. No. 05427, in which the prosecution forcibly drew blood from the defendant and tested it for HIV in order to determine whether assault charges should be elevated.

178. In R. v. Leaf (1926) 45 C.C.C. 236 , the Saskatchewan Court of Appeal upheld the conviction upon a charge of manslaughter of a man who communicated venereal disease to a woman who subsequently died as a result of the disease.

179. It would be possible for the person infected to predecease the transmitter as the clinical course of the disease can vary widely amongst AIDS patients, see Part IV(C) infra.

180. Apparently in $R$. v. Thornton, supra, note 169, the police considered charging the accused with attempted murder: "Ottawa Police Seizing Medical Files of Man Who Donated Tainted Blood", Globe and Mail, (February 24, 1988) p. A1. 
In addition to the transmission-related concerns described above, AIDS-related issues could present other problems within the criminal law sphere. For example, a seropositive defendant might argue that the disclosure of his antibody status to a jury, either directly or indirectly, could prejudice his right to a fair trial by an "impartial tribunal" under $\mathrm{s}$. 11(d) of the Canadian Charter of Rights and Freedoms. ${ }^{181}$ It is also possible that the prohibition in s. 12 of the Charter against cruel and unusual punishment might limit the sentencing options that could be imposed on a defendant suffering from AIDS or a HIV-related disorder. In a related vein, the fact that an inmate is suffering from AIDS might be a relevant consideration with respect to granting early parole. ${ }^{182}$

Finally, AIDS-related arguments might be offered as a defence or at least as a mitigating circumstance. In Alaska v. Foster, ${ }^{183}$ the defendant, who was charged with the first degree murder of another man, argued unsuccessfully that his depression over discovering that he was seropositive contributed to his inability to form the requisite mens rea. In People v. Owens ${ }^{184}$ the defendant admitted to having killed another man but sought to have the charges reduced from second degree murder to manslaughter. He argued that he was acting under "extreme emotional disturbance" as the victim had had sex with him and then had disclosed that he had AIDS.

\section{Tort Law}

There are several ways in which HIV transmission might be addressed by the law of torts. An act such as sexual intercourse or the administration of an IV drug by one person to another might constitute battery if it resulted in the transmission of HIV. The critical issue in such a case would be whether the undisclosed possibility of HIV transmission was of such import as to vitiate the consent of the plaintiff to the act. Alternatively, it might be possible for a cause of action in negligence to lie against someone who exposes another to HIV. While no such cases have arisen in Canada, there have been successful negligence suits in the United States involving the transmission of other infectious diseases ${ }^{185}$ and law suits have been filed

181. This could be a concern where the HIV antibody status of the defendant is not germane to the offence charged. In a wrongful death action, Ageloff v. Delta Airlines No. 86-8035-CIVScott (S.D. Fla.), the Court recognized the potential prejudice that could result from such a disclosure and under Fed R. Evidence 403 prohibited any mention being made of the fact that the deceased was a homosexual or that he had AIDS. Indirect disclosure could occur by requiring either the defendant or those attending him to wear protective clothing in court. Such clothing has been used in Canada and permitted in several American jurisdictions although it has been rejected as unnecessary in another civil case, In Re Peacock 59 B.R. 568 (Bkrtcy. S.D. Fla. 1986) in which the judge referred to an opinion by the C.D.C. that such precautions were unnecessary in a courtroom setting.

182. This has occurred in at least one case: "Convict Stricken With Virus Gets Early Release From Jail" Globe and Mail, (September 17, 1987) p. A17.

183. Superior Ct, 3AN-S871860; APL 2:13, (July 15, 1987).

184. APL 2:4 (March 11, 1987).

185. E.g., (Tuberculosis) Earle v. Kulko, 26 N.J. Super. 471, 98 A. 2d 107 (1953); (Smallpox) Franklin v. Butcher 144 Mo. App. 660, 129 S.W. 428 (1910); Hendricks v. Butcher 144 Mo. App. 671, 129 S.W. 431 (1910); (Venereal Disease) State v. Lankford, 29 Del. (6 Boyce) 594, 102 A. 3 (1917); Crowell v. Crowell, 180 N.C. 516, 105 S.E. 206 (1920); (Genital Herpes) Kathleen K. v. Robert B., 150 Cal. App. 3d 992, (1984) 198 Cal. Rptr. 273; Long v. Adams, $175 \mathrm{Ga}$. App. 538, 333 S.E. $2 \mathrm{~d} 852$ (1985). See generally "Tort Liability for Infliction of Venereal Disease" (1985) 40 A.L.R. (4th) 1083-1102. 
involving HIV transmission. For example, in C.A.U. v. R.L. the plaintiff is suing her former fiancé/sexual partner for negligently failing to inform her of his past sexual activities or of the fact that he had ARC. ${ }^{185}$

In situations where a person is exposed to HIV as a result of artificial insemination, the receipt of blood or blood products or due to an organ transplant, a suit based on general principles of products liability might be possible. In one Canadian case, Dort v. Canadian Red Cross Society, ${ }^{187}$ a young boy seroconverted after receiving blood transfusions during surgery. Several similar suits have been launched in the United States against blood banks, ${ }^{188}$ and manufacturers of blood products such as Factor IX which is used in the treatment of hemophilia. ${ }^{189}$ There is an additional difficulty in establishing negligence in many of these cases. As in Dort, many of the transfusions or other procedures which form the basis for the complaints occurred before 1985, i.e., before it was recognized that these were possible transmission routes for HIV and before tests for HIV antibodies were available. Indeed in Kozup and Georgetown University 190 and McKee v. Miles Laboratories Inc. ${ }^{191}$ claims based on negligence were dismissed for precisely this reason. Such suits also raise the question of whether agencies such as blood banks, etc., can be forced to reveal the names of their allegedly seropositive donors. In the United States such orders have been denied on the basis of the potential impact on both the donor as well as on the ability of blood banks to maintain a volunteer blood collection system. ${ }^{192}$ However, in Tarrant County Hospital District v. Hughes, ${ }^{193}$ the United States Supreme Court refused to review the decision of a lower court which ordered the disclosure of the names of donors in such a suit.

There are variety of other ways in which an AIDS-related issue might give rise to liability in tort. False suggestions that a person is HIV-positive or "has AIDS" could be dealt with in a number of ways. First, such an allegation could give rise to a libel or slander suit. It should be noted that Canadian law has already recognized as slanderous the false allegation that a person has a contagious disease. Such a case is actionable per se, i.e., damage is presumed and need not be pleaded. ${ }^{194}$ In the United States, statements of this nature relating to AIDS have given rise to both libel and

186. No. 86-11C480825, Dist. Ct., Ramsey City, Minn.

187. /C/1206/86. Ct. Q.B.N.B., Jud. Dist. St. John.

188. E.g., Stenger v. Miller Memorial Blood Bank Lehigh Cty. Ct. 87-C-586 (Pa.), APL 2:10 (June 3, 1987); Mathesonv. Irwin Memorial Blood Bank No. 864195 San Francisco Sup. Ct., Sept 18, 1986; Allen v. Irwin Memorial Blood Bank No. 863602 San Francisco Sup. Ct., Sept. 4, 1986; Roberts v. Suburban Hospital Association Inc. Md St Spec App, No. 201, APL 2:23 (Dec 2, 1987).

189. E.g., Coffee v. Cutter Biological and Miles Laboratories Inc. CA 2 No. 86-7583, APL 2:26 (Jan 13, 1988) p. 2; McKee v. Miles Laboratories Inc. DC EKy, CA No. 85-57, 86-248, APL 2:26 (January 13, 1988) p. 2; Doe v. Miles Laboratories Inc., Cutter Laboratories Division DC Md, CA No. R-86-2548, APL 2:26 (Jan 13, 1988) p. 1.

190. DC, Civil Action No. 86-0033, APL 2:13 (July 15, 1987) p. 3.

191. Supra, note 189.

192. Rasmussen v. South Florida Blood Bank 12 FLW 33 (Fla 1987); Taylor v. Central Blood Bank, Ct. Comm. Pleas, Allegheny Cty., CD No. GD 87-000206, AU 2:3 (Oct 1987) p. 1.

193. 734 S.W. 2d 675 (Tex. App. 2d Dist. 1987).

194. French (Oscar) v. Smith [1923] 3 D.L.R. 902; Houseman v. Coulson [1948] 2 D.L.R. 62. 
slander suits. ${ }^{195}$ Alternatively, such a statement might be actionable on the theory that the statement suggests that the person is a homosexual or an I.V. drug user. ${ }^{196}$ Additionally, such allegations might give rise to a valid claim for intentional infliction of mental suffering ${ }^{197}$ or negligent infliction of nervous shock. ${ }^{198}$ These causes of action are theoretically broader than defamation as they could reach cases involving truthful disclosure that an individual is seropositive. For example, in Doe v. Prudential Insurance Co. ${ }^{199}$ the plaintiff's suit for intentional infliction of emotional distress resulted from the dissemination of his positive HIV test results within an insurance company. Such a suit is not based on the inaccuracy of the statements but rather on the manner in which they are made.

Finally, AIDS might be relevant either as an explanation for a tortfeasor's actions or as an aggravating factor in the commission of an independent tort. Both of these elements were present in Doe v. Lacarenza Funeral Home, ${ }^{200}$ where the plaintiffs sued for intentional infliction of mental distress. In Doe, a mortician, citing non-existent state regulations, refused to embalm the body of a woman who had died as a result of an HIV-related disorder or to permit her body to be displayed in an open casket. As a result of these actions the woman's exposure to AIDS became generally known in her community. An example of AIDS being relevant as an aggravating factor is Dean v. Bowie ${ }^{201}$ where a prison guard who had been bitten and scratched by an inmate sued him for assault and battery. The relevance of AIDS was that the guard claimed damages for the disruption of his relationship with his wife due to a fear that he may have been exposed to HIV.

\section{Family Law}

Most of the AIDS-related cases which have arisen in the family law context have involved disputes over the awarding and structuring of child access and custody arrangements, where one of the persons seeking access or custody is a SP or PWA. Seropositivity might be considered relevant under legislation such as the Divorce Act where the factors to be considered

195. Rodway v. Los Angeles County/University of Southern California Medical Center, ACLU 101; Burton v. Yeager, Christ Reformed, United Church of Christ and Quakertown Community Hospital No. 87-0087 (Bucks Cty Ct of Comm Pleas), AU 2:2 (Aug, 1987) p. 1; Little v. Bryce, supra, note 112.

196. An imputation of homosexuality was recognized as slanderous in Nowark v. McGuire (1964), 255 N.Y.S. 2d 318 (C.A.); Buck v. Savage (1959), 323 S.W. 2d 363. Recognizing tort liability in this context does not require disapprobation of either homosexuality or IV drug use. This only requires a recognition that strong prejudices against such activity exist in our society and consequently such allegations could damage an individual's reputation in the community.

197. E.g., Doe v. Prudential Insurance Co. No. 87-CIV-2040, U.S. Dist. Ct., S.D.N.Y., APL 2:6 (April 8, 1988) p. 7; Burton, supra, note 195.

198. Such a claim could also arise in other contexts. E.g., in Halverson v. Brand, Pennsylvania Sup. Ct No. 01207 Phila., 1986, $A U:$ 2:5 (Feb 1988) p. 8, a nurse's suit for the negligent infliction of emotional distress was based on the failure of three doctors to inform her that a patient she had worked on was HIV positive.

199. Supra, note 197.

200. Conn. Sup. Ct., Stamford, No. CV 87-00909168, APL 3:1 (January 27, 1988) p. 6.

201. L/G LN 57 (October 1987). 
in awarding custody are "the best interests of the child ... as determined by reference to the conditions, means, needs and other circumstances of the child". ${ }^{202}$ The chief concern in these cases has been the fear of one of the parties that the child might be exposed to HIV through contact with the SP or PWA.

In one Canadian case, $\operatorname{Re} B,{ }^{203}$ the mother had been awarded custody of the couple's eight year old son. The father, who was homosexual, was given access to his son pursuant to an agreement which required, among other things, that: (i) the father conceal his homosexuality from his son; (ii) that no seropositive individual was to be permitted near the boy; and (iii) that the father was to be tested for HIV antibodies regularly, with the results being conveyed to the mother. When the father later tested HIV positive the mother applied for a change in the access order which would have permitted the father access only if he did not touch his son and if the child's paternal grandmother was present during visits to care for the boy's "personal needs". In a preliminary discussion with one Judge in that case the issue of absolute certainty arose with the Judge enquiring whether it could be guaranteed that the child would be $100 \%$ safe from infection.

Similar cases have arisen in the United States. In $W . v . W^{204}$ the issue is whether custody of a son, now living with his mother, should be awarded to the father who has AIDS but is presently well. The son has expressed a desire to live with his father, who had been the primary care-giver in the past. In Stewart v. Stewart ${ }^{205}$ a father lost visitation rights when he tested HIV positive. In this case the Judge said the order was necessary "because of the physical danger to the child". The question of absolute certainty arose again with the Judge stating that, "even if there is a one percent chance that this child is going to contract AIDS from the petitioner I'm not going to expose her to it".

The propriety of requiring HIV testing as a condition for access has also been considered. A cross-motion requiring the father to submit to an HIV antibody test was denied in In the Matter of Smalley. ${ }^{200} \mathrm{~A}$ similar result was reached through settlement in another case, In re the marriage of Susan Doe v. John Doe. ${ }^{207}$

While it is not reflected in the foregoing cases, another more legitimate concern would be whether the SP or PWA is healthy enough to adequately care for the child he wants access to, or custody of. Finally, seropositivity on the part of the child could also be a relevant factor with respect to determining what constitutes the child's "best interests".

202. Divorce Act, 1985 S.C. 1986, c. 4, as am. s. 16(8). Section $17(5)$ sets out the same factors for variations of custody orders. Provincial statutes can also be relevant re custody and access. E.g., Domestic Relations Act R.S.A., c. D-37, as am. ss. 54 and 56; Children's Law Reform Act R.S.O., c. 68, as am. s. 24.

203. $\operatorname{Re} B$, unreported, March 1, 1988, J.D. of York, S.C. $106402-84$ (Ont. H.C.) N.B. after entering an order on consent Mr. Justice Walsh ordered that the file in this case be sealed.

204. $A C L U 125$.

205. No. 49 A04-8702-CV-42, APP. from Marion Super. Ct., Civ. Div.

206. Ohio, No. 83-112, Dom. Rel. Ct., Muskingum Co., filed Dec 86.

207. No. 78 D 5050 Circuit Ct. of Cook Cty, Illinois Country Dept., Dom. Rel. Div. 


\section{POLICY, LEGAL AND MEDICAL ISSUES}

The foregoing provides ample evidence of the scope and significance of the AIDS-related legal issues that have arisen in the United States. Absent any indication that the Canadian public is more knowledgeable about, or tolerant of, the disease, it is fair to assume that a similar range of developments will occur in Canada. Such issues present a host of difficult policy and legal questions. Should Canadian legislators follow the American example and enact new legislation, or use existing legislation, ${ }^{208}$ to implement such measures as mandatory HIV testing, contact-tracing and notification of sexual contacts, quarantining of seropositive individuals who persist in high risk activity, etc.? Should intentional HIV transmission be made a criminal offence, or a statutory tort? Should any of the various statutes dealing with workplace health and safety regulations, child access and custody, or human rights be amended to deal specifically with AIDS? Would mandatory testing, contact tracing or quarantine violate the Charter? What would constitute the mens rea of criminal HIV transmission? How would the issue of causation be dealt with in cases involving criminal, or tortious, HIV transmission?

Equally important, the foregoing demonstrates that the resolution of such issues demands a thorough understanding of the medical aspects of AIDS. In particular, an analysis of the developments in both legislation and case law indicates that they consistently present the following medical issues.

\section{Immunopathogenesis}

The immunopathogenesis of AIDS refers to how the disease works. An understanding of the immunopathogenesis of AIDS is important generally in the sense that it is essential for any discussion of the other medical issues related to AIDS. Moreover, it is clear that ignorance of the disease's mechanisms can affect legal outcomes. This is demonstrated by a labour arbitration in which the arbitrator mistakenly thought that the HIV antibodies, not HIV itself, caused AIDS. As a result, he both misunderstood the significance of a positive blood test and greatly exaggerated the risk of transmission between the grievors, prison guards, and seropositive inmates. ${ }^{209}$

However, in addition to this general importance, an understanding of the immunopathogenesis of AIDS also has particular relevance to some of the areas of law discussed above. In the labour context for example, does it

208. Much existing legislation could be used in response to AIDS. For example, the Health Protection and Promotion Act S.O. 1983, c-10 as am., allows a Medical Officer to order a person to submit to a medical examination, to place themselves into the care of a physician, to conduct themselves in such a manner as not to expose another person to infection and/or to remain in quarantine.

209. State of Delaware, Dept of Corrections and AFSCME Loc 1726 Council 81 Delaware Public Employees 86 LA 849 (1986) The arbitrator stated, "The positive test means, as I understand the evidence that the person is carrying the antibodies which cause AIDS, and is capable of transmitting them to others. The person in short, is a carrier of the disease, who may never contract the disease himself but who plainly represents a danger to those who come in close contact to him." (Emphasis in the original) 
make any sense to claim, as the employer did in United Airlines, that it was in the health interests of the employee to be removed from flight duty so as to avoid being exposed to viruses and bacteria in the cabin? ${ }^{210}$ Are there any jobs in which this might be the case? The immunopathogenesis of AIDS is also very important for anti-discrimination law. As the controversy surrounding the Cooper Memorandum suggests, the issue of whether or not AIDS or other HIV-related conditions should be considered a "handicap" or a "physical disability" requires a thorough understanding of how the disease works.

\section{HIV Transmission}

The fear of contagion has been centrally involved in virtually all of the AIDS-related legal developments canvassed above. In the legislative sphere this was reflected most obviously in the broadening of the public health statutes in Alberta and British Columbia. ${ }^{211}$ However, this also was an element in the changes to the immigration regulations. ${ }^{212}$ The cases as well almost all involve this fear of transmission. The labour cases demonstrate a concern about the risk posed by seropositive employees to co-workers and customers. There was also the question of whether exposure to seropositive individuals or HIV infected materials could constitute a health and safety hazard. In anti-discrimination law an understanding of HIV transmission is most important for resolving the issue of whether the presumed contagiousness of a SP or PWA precludes him from advancing a successful claim of handicap discrimination. Such an understanding is also an obvious prerequisite for any decision about whether criminal or tortious liability should be attached to the intentional or negligent transmission of AIDS. In family law the question of transmission arises most commonly with respect to decisions about custody and access. The omnipresence of this fear of contagion suggests that transmission will be the most important concern in any AIDS-related legal issue.

When one considers HIV transmission with the above developments in mind several questions present themselves. How is HIV transmitted? Can HIV be transmitted through casual contact? Have all the possible routes of HIV transmission been discovered? Is it ever possible to say it is $100 \%$ certain that HIV transmission cannot occur in a given situation?

\section{Clinical Spectrum}

The clinical spectrum of AIDS is the range of HIV-related disorders. In labour law this will be central to the determination of such issues as the

210. Supra, note 116.

211. This concern with transmission is particularly clear in the Public Health Act of Alberta. Under s. 54 of the old act an isolation order was intended "to mitigate the disease" i.e., it was primarily for the benefit of the person quarantined. As amended the purpose of an isolation order under s. 54 is now "to mitigate that disease or to limit its spread to others".

212. It cannot be said that the changes to the immigration regulations simply reflect the policy of $s$. 19(1)(a)(ii) of the Immigration Act, supra, note 68, i.e., to avoid the creation of excessive demands on health and social services. Such a rationale, while relevant to restrictions on immigrants, would not justify the refusal to permit SPs or PWAs to enter Canada as visitors. 
amount of absenteeism that will result from HIV infection, what kind of work a PWA reasonably can be expected to perform and for how long, etc. Similar considerations will be important in family law when defining the "best interests" of a seropositive child or deciding whether the health of a SP or PWA will permit him to adequately care for a child. In antidiscrimination law an understanding of the clinical spectrum is obviously essential for any discussion of whether "AIDS" constitutes a handicap. It will also be central to any consideration of whether a complainant is otherwise capable of exercising the particular right in question. In criminal law and torts, the physical condition of a SP or PWA will be helpful in determining his knowledge of his condition, an essential element of either criminal or tortious liability. Similarly, the symptoms manifested by a SP will be relevant to the determination of whether he has fulfilled the various treatment obligations imposed by provincial health statutes. Also in torts, the clinical spectrum will be very important with regard to such issues as the quantification of damages and the determination of contributory negligence.

\section{A MEDICAL OVERVIEW OF AIDS}

\section{A. IMMUNOPATHOGENESIS}

To properly understand the immunopathogenesis of AIDS one must be familiar with some of the basic aspects of viral infection and the human immune system. ${ }^{213} \mathrm{~A}$ virus is a minute organism which consists of a single strand of genetic material surrounded by a protein envelope containing antigens, the identifying markers of the virus. Viruses can only reproduce in living cells of a host species and they are specialized, i.e., they will attack only certain cells. Once a virus is within a host species it enters cells and takes over their genetic machinery, directing them to produce exact copies of itself. The viruses thus produced in turn infect other host cells.

When a bacterium or other foreign substance enters the bloodstream an immune response occurs involving a variety of white blood cells: macrophages; B-lymphocytes, T4 helper/inducer lymphocytes; killer T-cells and T8 suppressor lymphocytes. The macrophages, the first to respond, use their appendages to attach themselves to the invaders and destroy them.

213. The information in the following section was derived principally from the following articles: T.W. Mak, "Virology of the Human Immunodeficiency Virus" in AIDS: A Perspective For Canadians, supra, note 7; P.F. Halloran, "Immunology of HIV Infection" in AIDS: $A$ Perspective For Canadians, supra, note 7; P. Beverley, Q. Sattentau, "Immunology of AIDS", Br Med J [Clin Res] (1987) 294:1536-1538; D. Ho, R. Pomerantz, J. Kaplan, "Pathogenesis of Infection with Human Immunodeficiency Virus", N Engl J Med. (1987); 317:278-286; M. Melbye, "The Natural History of Human T lymphotropic virus-III Infection: the Cause of AIDS", Br Med J [Clin Res] (1986) 292:5-12; J. Laurence, "The Immune System in AIDS", Scientific American (1985) 6(253):84-93; D. Bowen, H. Lane, A. Fauci, "Immunopathogenesis of the Acquired Immunodeficiency Syndrome", Ann Int Med. (1985) 103:704-709; D. Klatzmann, "Selective Tropism of Lymphadenopathy Associated Virus (LAV) for Helper-Inducer T Lymphocytes", Science (1984) 225:59-63; H. Royer, E. Reinherz, "T Lymphocytes: Ontogeny, Function, and Relevance to Clinical Disorders", N Engl J Med. (1987) 316:1136-1142. A good introduction for the medical layperson to these matters is provided by a videotape entitled The Immune System and AIDS, produced by the Ontario Ministry of Health. 
The macrophages retain the antigens of the virus and alert the T4 helper lymphocytes. For every viral antigenic pattern there is a corresponding T4 helper lymphocyte which, once notified, attaches to the virus and begins to multiply. The T4 lymphocytes also direct killer T-cells and B-lymphocytes to multiply. The killer T-cells, which are also keyed to specific antigenic patterns, seek out and destroy virus-infected cells, terminating the production of new viruses. The B-cells produce antibodies that match the antigenic pattern on the envelope of the virus. These antibodies slow down the viruses, making them an easier target for the macrophages. The antibodies themselves also destroy viruses. Once the infectious organism has been eliminated, the T8 suppressor lymphocytes proliferate and suppress the functioning of the T4 helper cells, terminating the immune response. While the immune response will terminate at this time, both the B-cells and the T-cells that are specific for the virus that initiated the response will remain. These cells are capable of controlling that infectious agent should it reenter the body, thus rendering the host immune to that virus.

HIV is a retrovirus, i.e., a type of virus which contains RNA as its genetic material. Once HIV enters a host species it binds to, and then enters, a host cell. While HIV is capable of entering a variety of cells it demonstrates a marked preference for T4 helper lymphocytes as a replication site. Once inside these cells the HIV is uncoated and, in a process involving an enzyme called reverse transcriptase, its RNA is transcribed into DNA. It is this DNA which is then integrated into the host cell's genetic information. At the point of HIV entry the host cell is permanently infected. However, there may be no immediate adverse health consequences to the host as the HIV may remain dormant in the infected cell for years. Then, for reasons not yet fully understood, the infected cell becomes activated and HIV replication occurs. It is at this point that the T4 helper lymphocyte is destroyed, although here too the precise mechanism is not fully understood.

It is the depletion of T4 helper cells that is the most serious cause of the immunodeficiency associated with AIDS. The role of the T4 helper lymphocytes is so pivotal that even a moderate decrease in their number severely disrupts the functioning of the immune system and creates the susceptibility to the wide range of opportunistic infections (OIs) that eventually take the lives of AIDS victims. HIV also disrupts the immune system in a variety of other ways. In addition to killing T4 helper cells, HIV can impair the proper functioning of the remaining T4 lymphocytes. HIV also has been found to infect macrophages, killer T-cells and B-cells. While HIV does not appear to kill these cells it does cause functional abnormalities in them. These abnormalities, in turn, further impair the immune response. Finally, HIV also infects nerve cells - the apparent cause of the neurological dysfunction often observed in AIDS patients.

The infectious agents that cause the OIs are ubiquitous in nature. Thus, once immunosuppression occurs an individual is at risk of developing OIs. Unlike certain other forms of viral infection, HIV infection and the resulting immunodeficiency are permanent. A number of factors contribute to this result. First, the DNA transcribed from the HIV is integrated into the genetic machinery of the cell which makes it difficult to eliminate 
the HIV without killing the host cells as well. Second, the fact that various other cells can survive HIV infection means that these cells can provide a safe haven for HIV. This may be even more true with respect to the infected nerve cells as their location in the central nervous system may isolate them from certain elements of the immune system. Third, the ability of the immune system to respond effectively to HIV infection depends on its ability to recognize HIV. This identification is complicated in two respects with HIV as there are several different strains of HIV and HIV seem to be adept at rapid antigenic variation.

\section{B. TRANSMISSION}

Given the severe health consequences associated with AIDS, the concern about the transmission of AIDS is understandable. Fortunately, HIV is not easily transmitted. Unlike other viruses such as those involved in measles or tuberculosis, it cannot be transmitted through the air. ${ }^{214}$ There is also no evidence that HIV can be transmitted by close personal contact, ${ }^{215}$ by food or water ${ }^{216}$ or by insects. ${ }^{217}$

Transmission of HIV involves exposure to the body fluid of a seropositive person. At this time HIV has been isolated from various body fluids. The highest levels of HIV have been detected in blood, ${ }^{218}$ semen, ${ }^{219}$ and

214. CDC, "ACIP recommendations for protection against viral hepatitis", $M M W R$ (1985) 34:329-35; C. Koop, "Surgeon General's Report on Acquired Immune Deficiency Syndrome", US DHHS (October 1986); Population Reports, "AIDS - A Public Health Crisis" (1986 Series L) No. 6:L-202; D. Vlahoz et al. "Transmission of human immunodeficiency virus within the health care setting", Occup Med State of the Art Reviews (1987) 2:429-50.

215. Infra, pp. 509-511.

216. CDC, "Summary: Recommendations for Preventing Transmission of Infection with Human T-Lymphotropic Virus Type III/ Lymphadenopathy-Associated Virus in the Workplace," MMWR (1985) 34:681; Population Reports, supra, note 214.

217. G.H. Friedland and R.S. Klein, "Transmission of the Human Immunodeficiency Virus", $N$ Eng JMed (1987) 317:1125-35, 1131. The authors cite three types of evidence which suggest that HIV is not transmitted by insects. First, HIV infection tends to be age specific, i.e., most cases occur in persons between the ages of 20 and 49 (the classic age distribution for sexually transmitted diseases). If HIV was transmitted by insects, one would not expect to find such a pattern since insects do not discriminate with respect to age in their biting habits. Second, studies of Bell Glade, Florida, the community with the highest HIV infection rate in the United States, have demonstrated that it was sexual behaviour and intravenous drug use which accounted for the patterns of infection and not transmission by insects, as was hypothesized by some. Third, serologic testing has indicated that seropositive individuals were not more likely than others to have been exposed to arthropod-transmitted diseases. Finally, there is no biological evidence of the presence of HIV in insects. A minority of scientists have suggested that sufficient research has not yet been done to rule out definitively the possibility of HIV transmission by insects. A summary of these arguments can be found in K. Leishman, "AIDS and Insects", The Atlantic Vol. 260 No. 3 (September 1987) p. 56.

218. F. Barré-Sinoussi, et al., "Isolation of a T-lymphotropic retrovirus from a patient at risk for the acquired immune deficiency syndrome (AIDS)", Science (1983) 220:868-71; R.C. Gallo, et al., "Frequent detection and isolation of cytopathic retroviruses (HTLV-III) from patients with AIDS and at risk for AIDS", Science (1984) 224:500-3; J.E. Groopman, et al., "HTLVIII in saliva of people with AIDS-related complex and healthy homosexual men at risk for AIDS", Science (1984) 226:447-9; D.D. Ho, et al. "HTLV-III in the semen and blood of a healthy homosexual man", Science (1984) 226:451-3; J.A. Levy, et al., "Infection by the retrovirus associated with the acquired immunodeficiency syndrome: clinical, biological, and molecular features", Ann Intern Med (1985) 103:694-699.

219. D.D. Ho, et al., supra, note 218; D. Zagury, et al., "HTLV-IIl in cells cultured from semen of two patients with AIDS", Science (1984) 226:449-51; J.A. Levy, et al., supra, note 218. 
cerebrospinal fluid. ${ }^{20}$ Less frequently, lower concentrations of HIV have been detected in vaginal secretions, ${ }^{221}$ saliva, ${ }^{222}$ breast milk, ${ }^{223}$ tears, ${ }^{224}$ urine, ${ }^{225}$ serum, ${ }^{225}$ and alveolar fluid. ${ }^{227}$ HIV has also been isolated in brain tissue, ${ }^{228}$ lymph nodes, bone marrow cells ${ }^{29}$ and skin. ${ }^{230}$ However, the mere fact that HIV can be isolated in a particular fluid or tissue does not mean that it is an important route of transmission. To date only blood and semen have been shown conclusively to transmit HIV although it is likely that transmission via breast milk and vaginal secretions also occurs. ${ }^{231}$ Moreover, the chances of becoming infected also depend on such other variables as the amount of the virus, the duration of the exposure and the particular route of exposure. ${ }^{232}$

\section{Known Routes of Transmission}

There are three known routes of HIV transmission: (i) Transmission via blood; (ii) Sexual transmission; and (iii) Perinatal transmission. Each of these will be discussed in turn and then the evidence that suggests that HIV is not transmitted by close personal contact will be discussed.

220. D.D. Ho, et al., "Isolation of HTLV-III from cerebrospinal fluid and neural tissues of patients with neurologic syndromes related to the acquired immunodeficiency syndrome", $N$ Eng J Med (1985) 313:1493-7; J.A. Levy, "Isolation of AIDS-associated retroviruses from cerebrospinal fluid and brain of patients with neurological symptoms", Lancet (1985) 2:586588.

221. M.W. Vogt, et al., "Isolation of HTLV-III/LAV from cervical secretions of women at risk for AIDS", Lancet (1986) 1:525-7; C.B. Wofsy, et al., "Isolation of AIDS-associated retrovirus from genital secretions of women with antibodies to the virus", Lancet (1986) 1:527-9.

222. D.W. Archibald et al., "Antibodies to human T-lymphotropic virus type III (HTLV-III) in saliva of acquired immunodeficiency syndrome (AIDS) patients and in persons at risk of AIDS", Blood (1986) 67:831-4; J.E. Groopman, et al., supra, note 218; D.D. Ho, et al., "Infrequency of isolation of HTLV-III virus from saliva in AIDS", $N$ Engl J Med (1985) 313:1606; G. Lecatsas et al., "Retrovirus-like particles in salivary glands, prostate and testes of AIDS patients", Proc Soc Exp Biol \& Med (1985) 178:653-655.

223. L. Thiry, et al., "Isolation of AIDS virus from cell-free breast milk of three healthy virus carriers", Lancet (1985) 2:891-2.

224. L.S. Fujikawa, et al., "Isolation of human T-lymphotropic virus type III from the tears of a patient with the acquired immunodeficiency syndrome", Lancet (1985) 2:529-30.

225. J.A. Levy, et al., supra, note 218.

226. B.A. Michaelis, J.A. Levy, "Recovery of human immunodeficiency virus from serum", JAMA (1987) 257:1327.

227. J-M. Ziza, et al., "Lymphadenopathy-associated virus isolated from bronchoalveolar lavage fluid in AIDS-related complex with lymphoid interstitial pneumonitis", $N$ Engl JMed (1985) 313:183.

228. D.D. Gabuzda et al., "Immunohistochemical identification of HTLV-III antigen in brains of patients with AIDS", Ann Neurol (1986) 20:289-95; S. Gartner et al., "Virus isolation from and identification of HTLV-III/LAV-producing cells in brain tissue from a patient with AIDS", JAMA (1986) 256:2365-71; D.D. Ho et al., supra, note 220; G.M. Shaw et al., "HTLV-III infection in brains of children and adults with AIDS encephalopathy", Science (1985) 227:177-82.

229. M. Melbye, "The natural history of human T lymphotropic virus-III infection: the cause of AIDS", Br. Med. J. (1986) 292:5-12.

230. G. Kolata, "Where is the AIDS virus harboured?" Science (1986) 232:1197.

231. Friedland and Klein, supra, note 217; Population Reports, supra, note 214.

232. R.A. Coates and J.K. Johnston, "Transmission of HIV and Natural History of AIDS" in AIDS: A Perspective For Canadians, supra, note 7; Population Reports, supra, note 214. 
[VOL. XXVI, NO. 3

\section{(a) Transmission via Blood}

Transmission of HIV via blood has occurred in three contexts: (i) After the transfusion of blood or blood products; (ii) Amongst intravenous (IV) drug users; and (iii) As a result of needle stick injuries or other accidental exposure to HIV positive blood by health care workers (HCWs).

\section{(i) Transfusion of Blood or Blood Products}

Transfusion of blood or blood products has resulted in $4.7 \%$ of the AIDS cases in Canada. ${ }^{233}$ Studies have estimated the risk of infection from exposure to an infected donor to be from $66 \%$ to $89 \% .234$ However, not all blood products transmit HIV. To date, whole blood, plasma, red blood cells, platelets and clotting factor concentrate have been implicated in HIV transmission. ${ }^{235}$ No other products prepared from blood (e.g. albumin, immunoglobulin, plasma protein fraction and hepatitis $B$ vaccine) have been shown to pose any risk. ${ }^{236}$ This is because HIV is inactivated by the process involved in the separation and manufacture of these products. ${ }^{237}$ More importantly, the risk of HIV transmission through blood or blood products virtually has been eliminated in both Canada and the United States by a programme involving the screening of donated blood and plasma, the heat treatment of clotting factor concentrates, and the screening of potential donors. ${ }^{238}$ While a case of HIV transmission as a

233. Surveillance Update, supra, note 26 .

234. Coates, supra, note 232.

235. B.L. Evatt et al., "Coincidental Appearance of LAV/HTLV-III antibodies in hemophiliacs and the onset of the AIDS epidemic", NEng JMed (1985) 312:483-486; Friedland and Klein, supra, note 217; J. Jason et al., "Human T-Lymphotropic retrovirus type III/lymphadenopathy-associated virus antibody", JAMA (1985) 253:3409-3415; Melbye, supra, note 229; T.A. Peterman et al., "Transfusion-associated acquired immunodeficiency syndrome in the United States", JAMA (1985) 254:2913-2917.

236. CDC, "Provisional public health interagency recommendations for screening donated blood and plasma for the virus causing acquired immunodeficiency syndrome", MMWR (1985) 34:1-5; CDC, "Safety of therapeutic immune globulins preparations with respect to the transmission of human T-lymphotropic virus type III/lymphadenopathy-associated virus infection", MMWR (1986) 35:231-233; Friedland and Klein, supra, note 217; D.J. Gocke et al., "HTLV-III antibody in commercial immunoglobin", Lancet (1986) 1:37-38; S. Kato et al., "Hepatitis B vaccination and AIDS", JAMA (1985) 254:54; L. Muylle et al., "No HTLVIII antibodies after HBV vaccination", $N$ Eng $J$ Med (1986) 314:581; G. Papaevangelou et $a l$. " "Risk of AIDS in recipients of hepatitis B vaccine", N Eng J Med (1985) 312:376; B. Poiesz et al., "Hepatitis B vaccine: evidence confirming lack of AIDS transmission", MMWR (1984) 33:685-687; R.S. Tedder et al., "Safety of immunoglobulin preparation containing anti-HTLV-III", Lancet (1985) 1:815; T.F. Zuck et al., "More on partitioning and inactivation of AIDS virus in immune globulin preparations", [Letter] N Eng J Med (1986) 314:1454-1455.

237. J.D. Piskiewicz et al., "Inactivation of HTLV-III/LAV during plasma fractionation", Lancet (1985) 2:1188-1189; Poiesz et al. supra, note 236; US DHHS, FDA. "Safety of immune globulins in relation to HTLV-III", FDA Drug Bulletin (1986) 16:3; W.B. White et al., "Passive Transfer of antibodies to human T-cell lymphotropic virus type III in patients receiving high-dose intravenous immunoglobulin", [Letter] JAMA (1986) 255:2602-2603; T.F. Zuck. supra, note 236.

238. The screening of donated blood was started in the United States in April, 1985 and in Canada in November of 1985: Friedland and Klein, supra, note 217; S. Roy et al., "False-positive results of confirmatory testing for antibody for HIV-I", (1987) CMAJ 136:612-4. 
result of a transfusion from a seronegative donor has been reported, ${ }^{239}$ the risk of transfusion-related HIV infection is infinitesimal. ${ }^{240}$ Nonetheless, in response to public demand, the Canadian Red Cross is currently in the process of establishing a national autologous blood transfusion service for elective surgery. ${ }^{2 A 1}$

\section{(ii) Intravenous (IV) Drug Use}

Intravenous (IV) drug use has been implicated by itself in $0.66 \%$, and in conjunction with homosexual or bisexual activity in another $2.4 \%$, of the reported AIDS cases in Canada. ${ }^{242}$ It is a far more significant factor in the United States where it is the sole risk factor in $17 \%$ of reported AIDS cases and is implicated in $25 \%$ of reported AIDS cases. ${ }^{243}$ There, its importance transcends the numerical. It has been described as "the principal bridge (of the AIDS epidemic) to other adult populations through heterosexual transmission and to children through perinatal transmission."2m

HIV transmission occurs as a result of the practice of sharing drug paraphernalia. Various "shooting" practices of IV drug users result in the contamination of both syringes and needles with blood. When these are used repeatedly by various persons, without proper sterilization, the risk of being exposed to HIV infected blood increases. ${ }^{245}$ Although a single exposure may be no more significant than a needle stick injury involving a $\mathrm{HCW}$, the problem is that an individual drug user may inject herself hundreds or thousands of times. While it has been difficult to study IV drug users, the studies that have been done suggest that factors such as the number of injections and the amount of needle sharing, rather than the type of drug used or the duration of drug use, affect the likelihood of HIV seropositivity. ${ }^{246}$ Indeed, one explanation for the far lower incidence of seropositivity among Canadian IV drug users, as compared to their American counterparts, is the greater availability of sterile needles and syringes in Canada. ${ }^{247}$

239. "Transfusion-associated human T-lymphotropic virus type III/lymphadenopathy-associated virus infection from a seronegative donor - Colorado", $M M W R$ (1986) 35:389-91.

240. Assuming a false negative rate of $3 \%$ for the ELISA test Friedland estimates that the risk in the United States is between $1 / 100,000$ and $1 / 1,000,000$, Friedland and Klein, supra, note 217; Bove estimates a risk of $1 / 250,000$, assuming a false negative rate of $4 \%$; J.R. Bove, "Transfusion-Associated Hepatitis and AIDS. What is the Risk?" N Eng J Med (1987) 317:242-5.

241. A. Gilmore, "Red Cross gets go-ahead for autologous blood service", CMAJ (1988) 138:157-9.

242. Surveillance Update, supra, note 26, p. 2.

243. MMWR (1988) 37:286-295.

244. Id. This observation is obviously not true in the Canadian context given the far fewer number of AIDS cases related to IV drug use.

245. For a description of these practices see Friedland and Klein, supra, note 217; and H.M. Ginzberg, "Intravenous Drug Abusers and HIV Infections: A Consequence of Their Actions", (1986) 14 Law, Medicine and Health Care 268-272.

246. Friedland and Klein, supra, note 217; R.E. Chaisson et al., "Human immunodeficiency virus infection in heterosexual intravenous drug users in San Francisco," Am J Public Health (1987) 77:169-72.

247. Coates, supra, note 232. 


\section{(iii) Needle-Stick Accidents/Accidental Exposure to HIV Positive Blood}

No Canadian case has yet been reported in which a $\mathrm{HCW}$ seroconverted after exposure to HIV positive blood. ${ }^{248}$ However, HIV infection has resulted from needle stick-injuries ${ }^{249}$ and exposures of either mucous membranes or inflamed, uncovered skin to HIV positive blood. ${ }^{250}$ While this demonstrates the possibility of HIV transmission in this manner, other similar accidents suggest that HIV is less easily transmitted than other diseases. For example, there have been reports of HCWs exposed to HIV and another disease who developed the other disease without seroconverting. ${ }^{2 s 1}$

However, without knowledge of the risk pools involved, the reports referred to above do not give any indication of what the risk of such transmission is. A more useful estimate of this risk is provided by five studies of HCWs accidentally exposed to HIV positive blood. ${ }^{252}$ Of the 770 HCWs who suffered such exposure only three subjects seroconverted. ${ }^{233}$ This figure represents a seroconversion rate of 1.3 to 3.9 per 1,000 exposed HCWs. ${ }^{254}$ Not only is this rate low but it is worth noting over $40 \%$ of the accidents resulting in seroconversion could have been avoided if existing safety guidelines had been followed. ${ }^{2 s s}$

(b) Sexual Transmission

AIDS is first and foremost a sexually transmitted disease. Sexual behaviour has been implicated in $91.9 \%$ of the reported adult AIDS cases in Canada. While homosexual or bisexual activity was involved in $84.5 \%$ of these cases, the remaining $7.4 \%$ resulted from heterosexual activity. Indeed, if one adds to these cases those involving persons with no identified

248. Id.

249. "Needlestick transmission of HTLV-III from a patient infected in Africa"' Lancet (1984) 2:1376-7; E. Oksenhendler et al., "HIV infection with seroconversion after a superficial needlestick injury to the finger", New Eng J Med (1986) 315:582; R.L. Stricof et al. , "HTLVIII/LAV seroconversion following a deep intramuscular needlestick injury", $N$ Eng $J$ Med • (1986) 314:1115.

250. "Update: human immunodeficiency virus infections in health-care workers exposed to the blood of infected patients", MMWR (1987) 36:285-9.

251. "Innoculation of Crytococcosis With Transmission of the Acquired Immunodeficiency Syndrome", New Eng JMed (1985) 313:267; Gerberding et al., "Transmission of Hepatitis B Without Transmission of AIDS By Accidental Needlestick", New Eng JMed (1985) 312:56.

252. M.S. Hirsh et al., "Risk of nosocomial infection with human T-cell lymphotropic virus III (HTLV-III)", $N$ Eng $J$ Med (1985) 312:1-4; S.H. Weiss et al., "HTLV-III infection among health care workers: association with needle-stick injuries", JAMA (1985) 254:2089-93; D.K. Henderson et al., "Risk of nosocomial infection with human T-cell lymphotropic virus type III/lymphadenopathy-associated virus in a large cohort of intensively exposed health care workers", Ann Intern Med (1986) 104:644-7; J.L. Gerberding et al., "Risk of transmitting the human immunodeficiency virus, cytomegalovirus, and hepatitis B virus to health care workers exposed to patients with AIDS and AIDS-related conditions", $J$ Infect Dis (1987) 156:1-8; E. McCray, "The Cooperative Needlestick Surveillance Group. Occupational risk of the acquired immunodeficiency syndrome among health care workers", $N E$ ng JMed (1986) 314:1127-32.

253. Friedland and Klein, supra, note 217 , p. 1126; N.B., seropositive individuals at risk for HIV infection for reasons unrelated to their occupation were excluded from this total.

254. Id.

255. Id. 
risk factors, most of which are thought to involve heterosexual transmission, the total attributable to heterosexual activity would be $10.2 \%$ of adult AIDS cases. ${ }^{256}$ Thus, AIDS is clearly not simply a disease of male homosexuals. In fact, it is likely that heterosexual activity is the chief route of HIV infection worldwide. ${ }^{257}$

The risk of HIV transmission from a single or multiple sexual encounters with a seropositive individual is not known. ${ }^{258}$ One study estimated the risk from penile-vaginal intercourse with a known seropositive individual without using a condom to be $1 / 500$ for one sexual encounter and $2 / 3$ after 500 sexual encounters. Use of a condom would reduce the risk to $1 / 5000$ for one sexual encounter and $1 / 11$ after 500 sexual encounters. ${ }^{259}$ Other sexually transmitted diseases can be transmitted by a single encounter ${ }^{260}$ and the risk of transmission increases with the number of encounters. ${ }^{251}$ While it appears that HIV is less easily transmitted, ${ }^{262}$ it is clear that one exposure can be sufficient for transmission to occur. ${ }^{263}$

Studies have attempted to ascertain what sexual practices or other factors increase the risk of HIV transmission. In both homosexual men ${ }^{264}$ and heterosexuals ${ }^{265}$ there appears to be a correlation between seropositivity and the number of sexual partners. The explanation for this is simple the greater the number of sexual contacts, the greater the chance of exposure to an infected individual.

Anal-receptive intercourse has also been found to be associated with seropositivity among homosexual men. ${ }^{260}$ While anal-receptive intercourse

256. Surveilance Update, supra, note 26, p. 2.

257. Friedland and Klien, supra, note 217.

258. M. Chamberland and T.J. Dondero Jr., "Heterosexually Acquired Infection with Human Immunodeficiency Virus (HIV): A View from the III International Conference on AIDS", [Editorial] Ann Intern Med (1987) 107:763-6; Friedland and Klein, supra, note 217, p. 1129.

259. N. Hearst and S.B. Hulley, "Preventing the Heterosexual Spread of AIDS: Are We Giving Our Patients the Best Advice?" JAMA (1988) 259:2428-2432.

260. Friedland and Klein, supra, note 217, p. 1129; T. Peterman, "Sexual transmission of human immunodeficiency virus", JAMA 1986; 256:2222-6.

261. Friedland and Klein, supra, note 217, p. 1129; R.R. Hooper, "Cohort study of venereal disease. 1. The risk of gonorrhea transmission from infected women to men", $A m J$ Epidemiol (1978) 108;136-44.

262. Friedland and Klein, supra, note 217, p. 1129.

263. For example, $50 \%(4 / 8)$ women who were artificially inseminated once with semen from a seropositive male seroconverted: G.J. Stewart, "Transmission of human T-cell lymphotropic virus type III (HTLV-III) by artificial insemination by donor", Lancet (1985) 2:660-2.

264. Coates, supra, note 232; W.J. Boyko, "The Vancouver Lymphadenopathy-AIDS Study: 5. Antecedent behavioural, clinical and laboratory findings in patients with AIDS and HIVseropositive controls", CMAJ (1986) 135:881-7; Friedland and Klein, supra, note 217, p. 1129 ; JJ.,Goedert et al. " "Determinants of retrovirus (HTLV-III) antibody and immunodeficiency conditions in homosexual men", Lancet (1984) 1:257:321-5; L.A. Kingsley et al., "Risk factors for seroconversion to human immunodeficiency virus among male homosexuals", Lancet (1987) 1:345-9; W. Winkelstein et al., "Sexual practices and risk of infection by human immunodeficiency virus: the San Francisco Men's Health Study", JAMA (1987) 257:321-5.

265. Coates, supra, note 232; Chamberland, supra, note 258; N. Clumeck et al., "Heterosexual promiscuity among African patients with AIDS", N Engl J Med (1985) 313:182; J.K. Kreiss et al., "AIDS virus infection in Nairobi prostitutes: spread of the epidemic to East Africa", NEngl J Med (1986) 314:414-8; Friedland and Klein, supra, note 217, p. 1129.

266. Supra, note 264. 
is not required for homosexual transmission, it may increase the risk. ${ }^{267}$ Vaginal intercourse can transmit HIV from men to women and from women to men although, as with other STDs, the risk is higher for women. That HIV can be transmitted from men to women is supported by the fact that $43.8 \%$ of the AIDS cases in Canada related to heterosexual activity, are women and the majority of such cases in the United States are women. This is further supported by studies of sexual partners of seropositive persons ${ }^{268}$ and by reports of HIV transmission as a result of artificial insemination. ${ }^{269}$ The frequency of female to male transmission is more contentious. While this may be a less efficient route, instances of femalemale transmission have been documented. ${ }^{270}$ Moreover, in the sexualpartner studies discussed above seropositive male partners of women with AIDS were identified. ${ }^{271}$

The majority of studies suggest that the risk of HIV transmission via oral-genital sexual contact is slight. ${ }^{27}$ Oral exposure to semen is associated with risk of transmission in both homosexuals ${ }^{273}$ and heterosexuals. ${ }^{274}$ However, one study of chimpanzees suggests that this is a less efficient transmission route than vaginal exposure to semen. ${ }^{275}$ The risk of HIV transmission involved in cunnilingus is not known although it was associated with seroconversion in one study. ${ }^{276}$ The chief difficulty in determining the risk of transmission via oral-genital sexual contact is that it usually occurs in conjunction with other sexual acts.

Similar problems exist with respect to calculating the risk of HIV transmission via oral exposure to saliva as a result of "deep kissing". While theoretically possible, no case of HIV transmission via saliva exchange has been reported. Generally this is discounted as a possible route for HIV

267. Coates, supra, note 232; Chamberland supra, note 258; Friedland and Klein, supra, note 217, p. 1129; Kreiss, supra, note 265; M.A. Fischl et al., "Evaluation of heterosexual partners, children and household contacts of adults with AIDS", JAMA (1987) 257:640-4; J.M. Mann, "Prevalence of HTLV-III/LAV in household contacts of patients with confirmed AIDS and controls in Kinshasa, Zaire", JAMA (1986) 256:721-4; R.R. Redfield et al., "Heterosexually acquired HTLV/LAV disease (AIDS-related complex and AIDS): Epidemiological evidence for female-to-male transmission", JAMA (1985) 254:2094-6.

268. J-P Allain, "Prevalence of HTLV-III/LAV antibodies in patients with hemophilia and their sexual partners in France", $N$ Engl J Med (1986) 315:517-518; Fischl et al., supra, note 267; Friedland and Klein, supra, note 217, p. 1129; C. Harris et al., "Immunodeficiency in female sexual partners of men with the acquired immunodeficiency syndrome", N Eng JMed (1983) 308:1181-3; J.K. Kreiss et al., "Antibody to human T-lymphotropic virus type III in wives of hemophiliacs: evidence for heterosexual transmission", Ann Intern Med (1985) 102:623-6; Mann, supra, note 267; R.R. Redfield, "Frequent transmission of HTLV-III among spouses of patients with AIDS-related complex and AIDS", JAMA (1985) 253:1571-3.

269. Stewart, supra, note 187.

270. Calabrese et al., "Transmission of HTLV-III infection from man to woman to man",NEng J Med (1986) 314:987; Friedland and Klein, supra, note 217, p. 1130; R.R. Redfield et al., supra, note 267.

271. Supra, note 268.

272. Coates, supra, note 232.

273. Supra, note 264; N. Mueller, "The Epidemiology of the Human Immunodeficiency Virus Infection", (1986) 14 Law, Medicine \& Health Care 250-8.

274. Chamberland, supra, note 258; Fischl, supra, note 267.

275. P.N. Fultz, "Vaginal transmission of human immunodeficiency virus (HIV) to a chimpanzee", J Infect Dis (1986) 154:896-900.

276. Fischl, supra, note 267. 
transmission. This conclusion is supported by two separate groups of studies. First, in the studies of the household contacts of PWAs discussed below, the sharing of items contaminated by saliva did not result in transmission. ${ }^{2 \pi}$ Secondly, studies of dental workers who are exposed to both saliva and blood have shown only one case of transmission and this particular case cannot be linked to saliva. ${ }^{278}$

In addition to sexual practices other factors which might affect the efficiency of sexual transmission of HIV include: the infectivity of the source partner; the susceptibility of the recipient partner; and variations of infectivity amongst different strains of HIV. However, the relative importance of such factors and how they interact is not known. ${ }^{279}$

\section{(c) Perinatal Transmission}

This is the cause of $87.9 \%$ of the pediatric AIDS cases in Canada ${ }^{200}$ as well as of the majority of pediatric cases in the United States. ${ }^{281}$ There are three possible routes for HIV transmission from an infected woman to her child: to the foetus as a result of maternal circulation, to the infant as a result of the ingestion or inoculation of blood or other fluids during labour and delivery, and to the infant via breast milk..$^{282}$ Unfortunately, the relative efficacy and frequency of each route is not known. However, it does appear that the rate of perinatal HIV transmission is approximately 40 to $50 \% .283$

\section{Close Personal Contact}

It is the fear of HIV transmission through casual contact that lies at the heart of most AIDS-related legal issues. While this is an issue of substantial public concern the available scientific evidence suggests that HIV transmission does not occur as a result of even close personal contact. This conclusion is supported by studies of HCWs and studies of the household contacts of PWAs.

(a) Health Care Workers

As indicated earlier there have been no reports of occupationally-related HIV transmission to a HCW in Canada. ${ }^{284}$ In the United States $5.5 \%$ of all AIDS cases involve HCWs which is consistent with the fact that HCWs

277. Friedland and Klein, supra, note 217, p. 1132; Infra, note 288.

278. Friedland and Klein, supra, note 217, p. 1133; Gerberding, supra, note 252; A study by R.S. Klein of 1,104 dentists and 127 hygienists, found one dentist who apparently was exposed to HIV through the dental treatment of a patient. However, the dentist had had approximately 10 needle-stick exposures during the preceeding 10 years: J. Jakush, "AIDS The disease and its implications for dentistry", JADA (1987) 115:395-403.

279. Chamberland, supra, note 258; Friedland and Klein, supra, note 217, p. 1129.

280. Surveillance Update, supra, note 26.

281. Friedland and Klein, supra, note 217, p. 1130; Coates, supra, note 232.

282. Id.

283. Id.

284. In Canada, HCWs exposed to HIV infected fluids have been monitored since September 1985. Of the $120 \mathrm{HCWs}$ who have suffered either parenteral or mucous membrane exposure to such fluids none have seroconverted: Coates, supra, note 232. 
make up 5.4\% of the workforce. Of the HCWs with AIDS, 95\% report involvement in some other high risk activity. This leaves 5\% of AIDS cases involving HCWs with no recognized risk factors - approximately the same percentage as in the general population. ${ }^{285}$ In the five studies of HCWs discussed above more than $1600 \mathrm{HCWs}$ who had been exposed to patients with AIDS or potentially infected bodily fluids were followed, without any evidence of seroconversion absent parenteral inoculation or other high risk activity. ${ }^{286}$ While some cases of HIV transmission as a result of noninoculation parenteral exposure have been documented these have involved substantial exposure to infected blood, and/or other body fluids ${ }^{287}$ of a kind highly unlikely to occur in a casual contact situation.

\section{(b) Household Contacts of PWAs}

There has yet to be a reported case in Canada or the United States of AIDS in a family member of a PWA in which other high risk activity is not present. Moreover, seven studies involving 491 household contacts of PWAs showed no seroconverters who did not have additional exposure to HIV transmission through one of the three routes of transmission discussed above. ${ }^{288}$ One case of HIV transmission to a mother from her seropositive child has been reported. However, the transmission occured only after the mother was exposed to the child's blood, bloody feces and other bodily fluids on a daily basis, for a considerable length of time, during which the mother took no sanitary precautions. ${ }^{289}$ As the CDC noted, such contact was "not typical of the usual contact that could be expected in a family setting"'200 and it certainly is very different from that likely to be encountered in other contexts involving casual contact.

285. Friedland and Klein, supra, note 217, p. 1131.

286. Friedland and Klein, supra, note 217, p. 1131; Of 837 subjects without any known parenteral or mucous membrane exposure only 1 was found to be seropositive. However, the evaluation of this subject for other risk factors was incomplete. It should be noted that this subject did report two needlestick injuries from patients whose HIV antibody status could not be determined.

287. CDC, "Update: human immunodeficiency virus infections in health-care workers exposed to the blood of infected patients", MMWR (1987) 36:285-9; Friedland and Klein, supra, note 217, p. 1131; P. Grint $e t$ al., "Two associated cases of the acquired immunodeficiency syndrome (AIDS)", Commun Dis Rep (1985) 42:4.

288. Friedland and Klein, supra, note 217, p. 1132. The 7 studies referred to by Friedland are; Fischl, supra, note 267; J.M. Jason et al., "HTLV-III/LAV antibody with immune status of household contacts and sexual partners of persons with hemophilia", JAMA (1986) 255:2125; D.N. Lawrence et al. " "HTLV-III/LAV antibody status of spouses and household contacts assisting in home infusion of hemophilia patients", Blood (1985) 66:703-5; Redfield et al., supra, note 268; M.F. Rogers et al. , "Can children transmit human T lymphotropic virus III/ lymphadenopathy-associated virus (HTLV-III/LAV) infection?" Presented at the Second International Conference on AIDS, Paris, June 23-25, 1986; B.R. Saltzman et al., "Lack of household transmission of HTLV-III/LAV infection", Presented at the Second International Conference on AIDS, Paris, June 23-25, 1986; P.A. Thomas, "Comparison of HTLV-III serology, T-cell levels and general health status of children whose mothers have AIDS with children of healthy inner-city mothers in New York", Presented at the First International Conference on AIDS, Atlanta, April 14-17, 1985.

289. CDC, “Apparent transmission of human T-lymphotropic virus type III/lymphadenopathyassociated virus from a child to a mother providing health care", $M M W R$ (1986) 35:76-9.

290. Id. 
Two other considerations support the conclusion that HIV transmission does not occur through casual contact. First, if transmission could occur in this manner, it would be expected that the disease would have spread more quickly and that there would be more cases among women, children and other non-high-risk groups. Second, the degree of intimacy involved in the three transmission routes discussed above indicates how difficult it is for HIV to be transmitted.

It is true that cases of AIDS have occurred involving individuals who report no recognized risk factors. ${ }^{291}$ However, these cases do not indicate the possibility of HIV transmission through either casual contact or some other unrecognized route. Rather, these cases are most likely the result of the following factors: (i) inadequate epidemiologic information with respect to the PWA; (ii) denial by the PWA of involvement in high risk activities which carry a significant social stigma, e.g., various sexual activities or IV drug abuse; and (iii) the restrictive approach currently used in classifying AIDS cases as resulting from heterosexual activity. ${ }^{292}$ Indeed, a recent study of the "unexplained" cases reported in the United States disclosed no evidence of new modes of HIV transmission. ${ }^{203}$

\section{CLINICAL SPECTRUM OF HIV-RELATED DISORDERS}

There is a spectrum of disease associated with HIV infection with AIDS representing only the most serious extreme. Any discussion of this spectrum is limited in two respects. First, while various stages of HIVrelated disorders have been recognized, the relationship between these stages is not yet fully understood. The recent emergence of the disease has made any long-term studies of its progression among sufficiently large cohorts impossible. Furthermore, estimating the rate of progression is complicated by difficulties involved in ascertaining the time of initial infection. Thus, the figures set out below, indicating the percentage of persons with one stage of HIV infection who will progress to the next stage and how long this will take, are not definitive. Second, "variability is still the rule" 294 when discussing the progression of the disease. This variability can result from an individual's particular susceptibilities, ${ }^{205}$ from variations in infectivity among different strains of $\mathrm{HIV}^{296}$ and/or the presence of a

291. Such cases constitute $2.8 \%$ of the AIDS cases in Canada and $3.0 \%$ of the cases in the United States, Surveillance Update, supra, note 26.; MMWR (1988) 37:286-295.

292. K.G. Castro et al., "Investigations of AIDS Patients With No Previously Identified Risk Factors", JAMA (1988) 259:1138-42: An AIDS case will only be classified as being caused by heterosexual transmission where the infected person is known to have had sexual contact with a person reported to have AIDS, reported to be seropositive, or reported to be at risk of HIV infection. If none of these criteria is met the case will be characterized as involving no identifiable risk factors. The problem with this method is that many heterosexuals have little or no idea of the serostatus of their sexual partner or partners or whether these people have previously engaged in high risk activities.

293. Id.

294. P.A. Volberding, "The Clinical Spectrum of AIDS - Implications for Comprehensive Patient Care", Ann. Inter. Med., 103:729-733 at 730 (1985).

295. D. Klatzmann et al., supra note 213 at 62.

296. Friedland and Klein, supra, note 217. 
range of co-factors. Thus it is impossible to offer any definitive predictions with respect to the clinical course of any seropositive individual.

The spectrum of HIV-related conditions can be classified into four categories, as illustrated in Figure 1. Each of these groups and their interrelationship will be discussed in turn. ${ }^{207}$

\section{Group I: Acute HIV Infection \& Group II: Asymptomatic Infection}

Both of these stages occur after an HIV infection has taken place and an antibody response has been stimulated. The precise time between HIV

\section{FIGURE 1: THE CLINICAL SPECTRUM OF HIV-RELATED DISORDERS}

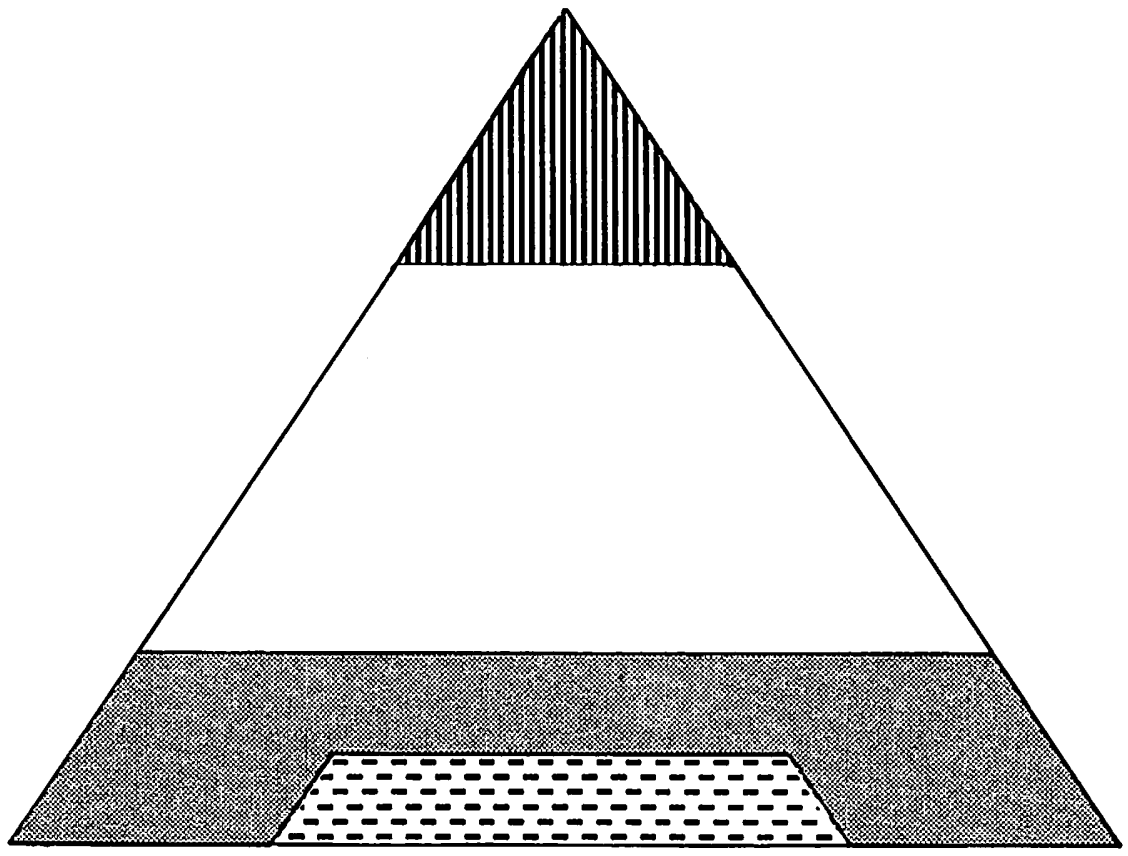

IIIII Group IV: AIDS

$\square$ Group III: ARC/PLS

Group II: Asymptomatic HIV Infection

E- Group I: Acute HIV Infection

297. The classification used here is a modification of the classification suggested by the CDC (MMWR 35:334-339, (1986)). The difference is that Group 3 has been broadened from the CDC category of Persistent Generalized Lymphadenopathy to include the range of signs and symptoms now known as AIDS-related complex (ARC). While ARC is now recognized as part of the clinical spectrum of HIV infection it did not fit into the original CDC classification system. At least two other classification systems have been suggested: H.W. Haverkos et al., "Classification of HTLV-III/LAV-related Diseases" (letter) $J$ Infect Dis (1985) 152:1095; R.R. Redfield et al., "The Walter Reed Staging Classification for HTLVIII/LAV Infection", New Eng JMed (1986) 314: 131-132. 
exposure and seroconversion is unknown. ${ }^{208}$ Group I individuals develop seroconversion illness, an acute syndrome similar to mononucleosis or influenza, within two to six weeks after initial infection. Symptoms may include fever, malaise, sweats, sore throat and generalized lymphadenopathy. ${ }^{209}$ Group I individuals may also present with encephalopathy (cerebral irritation), myalgia (muscle ache), anthralgia (aching joints), nausea, rashes and, in some rare cases, neurological symptoms such as seizures, loss of memory, personality changes and temporary motor impairment. ${ }^{300}$ These symptoms generally persist for approximately a week after which time these persons, while still infected, become asymptomatic and can be reclassified into Group II. Group II individuals are HIV infected but present no signs of HIV infection other than seropositivity. The majority of seroconverters experience no adverse health consequences, except perhaps a slight fever at the time of HIV infection. ${ }^{301}$

The prognosis for Group I and Group $\mathrm{II}^{302}$ persons is difficult to state with precision. It is possible for an infected person to remain asymptomatic for years, with the development of symptoms occurring from one and one-half to seven years ${ }^{303}$ after infection. Moreover, the clinical course of seropositive individuals can vary - some will develop ARC and then AIDS, while others may bypass ARC completely, presenting no other symptoms until the onset of frank AIDS. In addition, the percentage of Group II individuals who will develop ARC or AIDS varies between high

298. Seroconversion usually takes between six to twelve weeks: Coates, supra, note 232; CDC, "Public Health Service Guidelines for Counseling and Antibody testing to Prevent HIV Infection and AIDS", MMWR (1987) 36:509-15; Population Reports, supra, note 214, p. L197; N. Mueller, "The Epidemiology of the Human Immunodeficiency Virus Infection", (1986) 14 Law, Medicine \& Health Care 250-258 at 253. However, it may take six to fourteen months and some HIV infected persons appear to produce no antibodies whatsoever: Laurence, supra, note 213; K. Krohn et al., "Long Latency Precedes Overt Seroconversion In Sexually Transmitted Human-Immunodeficiency-Virus Infection", Lancet (1987) 2:589593.

299. M.W. Adler, "ABC of AIDS: Range and Natural History of Infection", Brit Med $J$ 194:1145-1147, May 2, 1987; A. Mindel, “ABC of AIDS: Management of Early HIV Infection", Brit Med J (1987) 294:1214-1218; Laurence, supra, note 213; Population Reports, supra, note 214, L-197; K.H. Mayer, "The Clinical Challenges of AIDS and HIV Infection", (1986) 14 Law, Medicine \& Health Care 281-289; M. Melbye, "The natural history of human T lymphotropic virus-III infection: the cause of AIDS", Brit Med J(1986) 292:5-12 at 9.

300. Mindel, supra note 299, p. 1214; C.A. Carne, "ABC of AIDS: Neurological Manifestations", Brit Med J. (1987) 294:1399-1401.

301. Mayer, supra, note 299; Boyko et al., "The Vancouver Lymphadenopathy-AIDS Study: 7. Clinical and Laboratory features of 87 cases of Primary HIV infection", CMAJ (1987) 137:109-113.

302. Both Group I and Group II individuals can be discussed together for these purposes.

303. Population Reports, supra, note 214, p. L-201; Curran, supra, note 28, p. 1354; Adler, supra, note 299 , p. 1146. 
risk groups. ${ }^{304}$ However, current indications are that a seropositive person has a $35 \%$ chance of developing AIDS within five years. ${ }^{305}$

\section{Group III: ARC/PLS}

AIDS-related complex (ARC) or persistent lymphadenopathy syndrome (PLS) is the next stage of HIV infection. Individuals with ARC present a variety of symptoms of AIDS without the opportunistic infections or tumours found in AIDS patients. The third CDC category, persistent generalized lymphadenopathy (PGL), is defined as swollen lymph nodes at two or more sites, other than the groin, persisting for more than three months. ${ }^{306}$ PGL is a sufficient basis for a diagnosis of ARC. However, lymphadenopathy can also occur in conjunction with night sweats, anorexia, fever, weight loss (greater than $10 \%$ of body weight), diarrhea, fatigue and uncommon infections such as oral candidiasis (thrush) and herpes zoster (shingles). ${ }^{307}$ These symptoms will vary in severity and may occur intermittently or on a more persistent basis. While some combinations of these symptoms may occasionally be incapacitating they have greater importance as prognostic markers. Specifically, the presence of oral candidiasis, herpes zoster, fever, malaise, diarrhea and weight loss are considered good predictors of a subsequent progression to AIDS. ${ }^{308}$

304. It has been estimated that each year 8 to $10 \%$ of Group II individuals will develop further symptoms. In one study of seropositive homosexuals in San Francisco $47.3 \%$ (27/s7) developed other symptoms over a median of 5 years: Population Reports, supra, note 214, p. L-201. Another study of high risk blood donors evaluated a median of 29 months after donation, found $26.7 \%(8 / 30)$ had developed lymphadenopathy: HW Jaffe et al., "Infection with HTLV-III/LAV and transfusion associated acquired immunodeficiency syndrome", $J A M A$ (1985) 254:770-773. The number of Group II individuals who will eventually develop AIDS has been estimated to be from 2 to $30 \%$; A.M. Macher, "The Medical Background" in A\&L II, supra, note 8; L. Mass, "Medical Answers About AIDS" in AIDS: The Workplace Issues (1983); Johnson and Soskolne, supra, note 7. Others have suggested that each year 2 to $10 \%$ of seropositive persons will develop AIDS; Population Reports, supra, note 214 (2 to $10 \%$ ); Laurence, supra, note 213 (says an estimate of $7 \%$ is probably conservative). The San Francisco study referred to above found AIDS in $17.5 \%(10 / 57)$ of the homosexual males while the study of high risk donors found 13.3\% (4/30) had developed AIDS; Population Reports, supra, note 214. Another study which compared the incidence of AIDS after 3 years in 5 different cohorts of seropositive members of high risk groups found incidences of AIDS ranging from 4.2\% (1/24) to 29.5\% (13/44): J.J. Goedert, "Three Year Incidence of AIDS in Five Cohorts of HTLV-III Infected Risk Group Members", Science (1986) 231:992. The incidence by group was: Manhattan homosexuals $29.5 \%$ (13/44); Washington D.C. homosexuals 14.3\% (6/42); Danish homosexuals 7.7\% (2/26); Queens, N.Y. IV drug users $4.2 \%$ (1/24); and Pennsylvania haemophiliacs $12.5 \%(5 / 40)$.

305. L.O. Gostin et al., "The Case Against Compulsory Casefinding in Controlling AIDS Testing, Screening and Reporting" (1987) 12 Am. J. Law \& Med. 7, 19.

306. $M M W R$ (1986) 35:334-39.

307. M.S. Gottlieb, "Immunological Aspects of the Acquired Immunodeficiency Syndrome Syndrome and Male Homosexuality", Med Clin. of N. Am. (1986) 70:651 at 655; Population Reports, supra, note 214 at L-199; F.A. Shepherd et al., "A guide to the investigation and treatment of patients with AIDS and AIDS-related disorders", CMAJ (1986) 134:999-1008, at 1001; Mayer, supra, note 299, p. 282. N.B., A diagnosis of ARC is only proper if the symptoms cannot be explained with reference to another disease and have persisted for more than a month; Mindel, supra, note 299, p. 1215.

308. Mindel, supra, note 299, p. 1218. 
Here again the clinical course of Group III individuals can vary widely. ${ }^{309}$ However, it does seem clear that the proportion of people with ARC who develop AIDS does increase with time. ${ }^{310}$

\section{Group IV: AIDS}

AIDS is the end stage of HIV infection and can involve a variety of OIs, cancers and neurological complications. ${ }^{311}$ The collapse of the immune system also facilitates the multiplication of malignant cells and the development of cancers. The neurological complications can result from OIs or cancers, as well as HIV infection of the brain, spinal cord and other parts of the central nervous system. The prognosis for any particular AIDS victim will depend on the pathological constellation of his case. The various illnesses that can afflict an AIDS patient vary in severity and may occur simultaneously or sequentially. ${ }^{312}$ Remission of certain of these diseases is not uncommon and some respond well to conventional treatment. However, the bottom line remains morbidly chilling - it appears that few persons, if any, can survive full-blown AIDS. Estimates of average survival time do not exceed two years.$^{313}$ The statistics in Canada

309. It has been estimated variously that $5 \%$ to $30 \%$ of Group III individuals will ultimately develop AIDS: J.D. Henry, "AIDS In The Workplace" in $A \& L I I$, supra, note 8, p. 34 (5\% to $20 \%$ ); Mass, supra, note 304, p. 62 (9\% to 30\%); Adler, supra, note 299, p. 1145 (10\% to $30 \%$ ). However, here again studies have produced a variety of results ranging from $7 \%$ (14/200) after lymphadenopathy for a mean of 29 months to $29 \%$ (12/42) after 4.5 years; D.I. Abrams, "Lymphadenopathy Related to Acquired Immunodeficiency Syndrome in Homosexual Men", Med Clin of N Am (1986) 70:693-706; U. Mathur-Wagh et al., "Follow Up at 41/2 Years On Homosexual Men with Generalized Lymphadenopathy" [Letter], New Eng J. Med (1985) 313:1542-1543. Other studies include; C.A. Carne et al., "From Persistent Generalized Lymphadenopathy to AIDS: Who Will Progress?", Br. Med J [Clin Res] (1987) 294:868-869 - 13\% (13/100 followed for a median of 24 months); and C.E. Metroka et al., "Generalized Lymphadenopathy in Homosexual Men: An Update of the New York Experience", Ann. N.Y. Acad. Sci (1984) 437: 400-411 - 24\% (22/90 after 31 months); H.W. Murray et al., "Patients at Risk for AIDS-related opportunistic infections: clinical manifestations and impaired gamma interferon production", New Eng J. Med. (1985) 313:1504-1510 - 20.2\% (14/69 after 14 months); D.B. Fishbein et al., "Unexplained lymphadenopathy in homosexual men: a longitudinal study", JAMA (1985) 254:930-935 $6.6 \%$ ( $3 / 75$ after a median of 29.5 months).

310. Adler supra, note 299, p. 1145.

311. On August 14, 1987 the CDC revised its surveillance case definition for AIDS. The precise definition depends on the HIV status of the subject. In a seropositive individual, AIDS is defined by the presence of a variety of indicator diseases regardless of whether or not another cause of immunodeficiency exists. In a seronegative individual, a diagnosis of AIDS requires, in the absence of any other cause of immunodeficiency, either the presence of PCP or the presence of a more limited range of indicator diseases coupled with a reduced T4 helper lymphocyte count. Where the HIV status is undetermined AIDS can be diagnosed if the more limited range of indicator diseases is present without there being any other cause for immunodeficiency.

312. L.S. Young, "Management of Opportunistic Infections Complicating the Acquired Immunodeficiency Syndrome" Med Clin of N Am (1986) 70:677-692.

313. D.I. Abrams, "Routine Care and Psychosocial Support of the Patient With the Acquired Immunodeficiency Syndrome", Med Clin of N Am (1986) 70:707-720; G.F. Solomon et al., "An Intensive Psychoimmunologic Study of Long-Surviving Persons with AIDS", Ann. N. Y. Acad. Sci (1987) 496:647-655. 
bear this out — of the 1809 cases of AIDS diagnosed to date, $56.3 \%$ (1018) have resulted in fatalities. ${ }^{314}$

As many as two dozen opportunistic complications have been associated with AIDS and the clinical spectrum is constantly expanding. However, the following are the most common AIDS-related conditions:

(a) Pneumocystis Carinii Pneumonia (PCP)

This is the most common AIDS-related OI in Canada. PCP appears by itself in $55.0 \%$ of adult AIDS cases and in conjunction with Kaposi's Sarcoma (KS) in another $2.5 \%$ of the cases. ${ }^{315}$ The symptoms of PCP include a six to eight week history of shortness of breath, fever, nonproductive cough and/or tightness in the chest ${ }^{316}$ and PCP seems to last longer in AIDS victims than in others. ${ }^{317}$ If untreated, PCP has a mortality rate of $100 \%$ and remission is rare. ${ }^{318}$ PCP is the chief cause of death in AIDS victims, often in conjunction with another infection. While $75 \%$ of patients survive a first episode of PCP, the recurrence rate is 20 to $30 \%{ }^{319}$ Subsequent life expectancy for an AIDS patient with PCP is short, with estimates ranging from nine months in the United States to twelve and onehalf months in the United Kingdom. A survival time of two years is rare. ${ }^{320}$ The mortality rate increases and the median survival time decreases when PCP presents with another infection ${ }^{321}$ or where a patient suffers a subsequent episode. ${ }^{322}$

(b) Kaposi's Sarcoma (KS)

After PCP, this cancer of the blood vessels is the second most common medical problem associated with AIDS. It has appeared by itself in $19.9 \%$ of adult AIDS cases in Canada and in another $2.5 \%$ in conjunction with PCP. ${ }^{323}$ The first sign of KS is often multiple purplish or red lesions

314. Surveillance Update, supra, note 26, p. 1. The experience in the United Kingdom and the United States is similarly devastating. As of March, 1987, 54.7\% (782/1429) of the AIDS cases in the U.K. and as of June, 1988, 56.5\% $(37,195 / 65,780)$ of the AIDS cases in the United States had resulted in deaths; Surveillance Update, supra, note 26, pp. 8-9.

315. Id.

316. A. Millar, "ABC of AIDS: AIDS and the Lung", Brit Med J [Clin Res] (1987) 294:133413377; Mayer, supra, note 299, p. 282.

317. L.A. Engelberg et al., "Clinical Features of Pneumocystis Pneumonia in the Acquired Immune Deficiency Syndrome", Am. Rev. Resp. Dis. (1984) 130:689-694; J.A. Kovacs et al., "Pneumocystis Carinii Pneumonia: A Comparison Between Patients with the Acquired Immunodeficiency and Patients with other Immunodeficiencies", Ann. Intern Med (1984) 100:663-671.

318. P. Hurley et al., "Unusual Remission of Pneumocystic Carinii Pneumonia In A Patient With the Acquired Immune Deficiency Syndrome", Am. J. Med. (1987) 82 (3 Spec No): 645-648.

319. Young, supra, note 312, p. 681 .

320. Millar, supra, note 316, p. 1334.

321. Young, supra, note 312.

322: A mortality rate of $35 \%(6 / 17)$ has been found in a study of patients admitted to hospital a second time for PCP compared to a mortality rate of $19 \%(23 / 124)$ for first time admissions; C.P. Kales et al., "Early Predictors of In-Hospital Mortality for Pneymocystis Carinii Pneumonia in the Acquired Immunodeficiency Syndrome", Arch Intern Med (1987) 147:1413-1417.

323. Surveillance Update, supra, note 26, p. 2. 
appearing in the mouth, other mucous membranes or almost any area of the skin. These lesions, which often multiply, can develop over months to become painless nodules. KS can also affect the gastrointestinal tract and lungs. However, the course of KS can vary widely and remission is common. ${ }^{324}$ While KS can lead to potentially fatal internal haemorraging, it is rarely life threatening and patients usually die of another OI.$^{325}$ Often the most serious effect of KS is the psychological and social consequences of the appearance of the lesions. Their presence often affects the patient's self-image and the reactions of others to the visible manifestation of the patient's AIDS. ${ }^{326}$ While some victims of KS may remain well for as long as three to five years, ${ }^{327}$ the overall mortality rate for $\mathrm{KS}$ is about $41 \%$ and a more usual survival time is estimated to be eighteen months. ${ }^{328}$

\section{(c) Malignant Lymphomas}

The other type of cancer found most often in AIDS patients is a B cell lymphoma. Like KS, this tumour appears much more commonly in homosexuals than in members of other high risk groups. ${ }^{329}$ These lymphomas are frequently accompanied by fever and weight loss. The prognosis for AIDS-related lymphomas is poor, they respond poorly to chemotherapy and relapse after chemotherapy is high. Mean survival time is less than a year, with most patients dying as a result of their lymphoma, although in some cases the cause of death may be another OI. ${ }^{330}$

\section{(d) Subacute Encephalitis}

Approximately one third of AIDS patients develop subacute encephalitis which can develop into AIDS dementia. Symptoms can include confusion, forgetfulness, loss of concentration, slowness of thought, loss of balance, leg weakness, lethargy and loss of libido. It can become severe over a period of weeks and months leaving the patient bedridden and incontinent. ${ }^{331}$

\section{(e) Cryptococcus Meningitis}

This is the most common form of meningitis in AIDS patients and is caused by the fungus Cryptococcus neoformans. Headache is the most

324. J.J. Brooks, “Kaposi's sarcoma: a reversible hyperplasia", Lancet (1986) 2:1309-1311.

325. Population Reports, supra, note 214, p. L-200; Mayer, supra, note 299, p 283; N. Smith and M. Spittle, "ABC of AIDS: Tumours", Brit Med J [Clin Res] (1987) 294:1274-1277.

326. P.A. Volberding, "Kaposi's sarcoma and the acquired immunodeficiency syndrome", Med Clin North Am (1986) 70:665-75; B. Safai et al., "The natural history of Kaposi's sarcoma in the acquired immunodeficiency syndrome", Ann Intern Med (1985) 103:744-750.

327. M.M. Fanning, "Clinical Aspects of HIV Infection" in AIDS: A Perspective For Canadians, supra, note 7; Population Reports, supra, note 214, p. L-200; Abrams, supra, note 313.

328. Fanning, supra, note 327; Safai, supra, note 326.

329. Smith and Spittle, supra, note 325, p. 1276.

330. Smith and Spittle, supra, note 325; Mayer, supra, note 299, p. 283.

331. Fanning, supra, note 327; C.A. Carne, "ABC of AIDS: Neurological Manifestations", Brit Med J [Clin Res] (1987) 294:1399-1401; I. Grant, "Evidence for Early Central Nervous System Involvement in the Acquired Immunodeficiency Syndrome (AIDS) and Other Human Immunodeficiency Virus (HIV) Infections", Ann Intern Med (1987) 107:828-836; Ho et al., "Pathogenesis of Infections with Human Immunodeficiency Virus", New Eng J Med (1987) 317:278-286; Mayer, supra, note 299, p. 283-284. 
common symptom of this condition although patients may also experience nausea, blurred vision and neck stiffness. This meningitis is fatal if untreated and even with treatment it can have a mortality rate of up to $25 \%$. Bloodstream infection and pneumonia can also result from cryptococcal infection..$^{332}$

\section{(f) CNS Toxoplasmosis}

This brain disease, also commonly seen in patients with AIDS, is caused by the protozoan Toxoplasma gondii. The symptoms, which usually develop over one to two weeks, include severe headache, confusion and lethargy. This disease can also cause cerebral space-occupying lesions which can lead to seizures and focal neurological defects. If untreated, this condition is fatal. While a positive response to treatment is often quite prompt, relapses are common and treatment might be required for life. ${ }^{333}$

\section{(g) Mycobacterial Infection}

Mycobacterial infections are caused by mycobacterium avium-intracellulare (MAI) and mycobacterium tuberculosis (TB). MAI is the more common and often occurs in patients who have experienced a series of other OIs. $M A I$ can lead to protracted fever, liver dysfunction and AIDSwasting syndrome. The prognosis for $M A I$ infection is poor and no effective treatment has been developed. $T B$ can cause fever, cough, sputum production and in some cases can affect other organs. $T B$ does respond well to conventional treatment but its appearance may foreshadow the development of other serious HIV infections. Also, unlike $M A I, T B$ can be highly infectious. ${ }^{334}$

\section{(h) Cryptosporidosis}

Cryptosporidosis is another protozoan disease which causes debilitating diarrhea. It is very difficult to treat and can last for weeks and possible months. This disease can prove fatal unless the patient receives adequate fluid replacement and nutritional supplements. No drug has proven to be consistently effective in combatting this condition and relapse is common after treatment. ${ }^{335}$

\section{(i) Cytomegalovirus (CMV)}

CMV is sexually transmitted and is commonly found in AIDS victims. In PWAs this virus can cause retinitis, meningitis, mononucleosis, pneumonia and infections of the esophagus, colon and adrenal glands. CMV also seems to have an independent immunosuppressive effect which can contribute to the development of other OIs. ${ }^{336}$

332. Young, supra, note 312, p. 688; Population Reports, supra, note 214, p. L-200; Mayer, supra, note 299, p. 282; Carne, supra, note 331, p. 1399.

333. Population Reports, supra, note 214, p. L-200; Mayer, supra, note 299, p. 282-283; Carne, supra, note 331, p. 1400; Young, supra, note 312, p. 683; Shepherd, supra, note 307, p. 1004.

334. Population Reports, supra, note 214, p. L-200; Mayer, supra, note 299, p. 283; Young, supra, note 245, pp. 685-687; Millar, supra, note 316, p. 135.

335. Population Reports, supra, note 214, p. L-200; Mayer, supra, note 299, p. 283; Young, supra, note 238, p. 685; Shepherd, supra, note 307, p. 1004.

336. Millar, supra, note 316, p. 1335; Mayer, supra, note 299, p. 283. 


\section{CONCLUSION}

The medical significance of AIDS is tragically obvious. AIDS is a fatal disease that is currently incurable and is likely to be with us well into the forseeable future. The legal significance of AIDS, while not as selfevident, is becoming clearer as the developments canvassed in Part II demonstrate. Indeed, Part II is only illustrative of a range of AIDS-related legal developments which are likely to occur in Canada. These developments are particularly challenging because they not only present complex legal questions but they also demand a thorough understanding of a widely misunderstood and dreaded disease. Therefore, the medical information outlined in Part III is a necessary prerequisite for any resolution of AIDSrelated issues. However, in addition, a proper understanding of AIDS also simplifies or eliminates some of the legal problems presented in Part II.

First, the fear of HIV transmission which is implicated in the vast majority of AIDS-related cases is simply not merited. The fact that HIV can only be transmitted by particularly intimate contact suggests that such concerns will rarely if ever require the differential treatment of a SP or a PWA. Thus, the concern seen in the labour cases about seropositive employees or clients is unfounded in the vast majority of cases, including those in the medical sphere. Similarly, the risk of transmission cannot be said to necessitate restrictions on the custody and access rights to seropositive parents. Nor can fears about transmission constitute a defence to a complaint of discrimination on the basis of disability or handicap.

The fact that HIV is not easily transmitted also means that quarantine is not an appropriate response to AIDS except perhaps in the rare case where a seropositive person continues to engage in high risk activities. Thus, the amendments to the public health legislation in Alberta and British Columbia would appear to be an over-reaction to the fear of contagion.

Second, an understanding of the immunopathogenesis of HIV-related disorders requires that almost any attempt to justify restrictions on SPs or PWAs on the grounds that such restrictions are necessary to protect their health be rejected. As opportunistic infections result from exposure to infectious agents which are ubiquitous in nature, seropositive individuals will not gain any real health benefit from being laid off, isolated, etc. Therefore, the "altruistic" defence offered by the employer in United Airlines should not be accepted. ${ }^{337}$ Similarly, quarantine of a SP or PWA cannot be justified in terms of protecting his own health.

Third, it is clear from the discussion of the clinical spectrum of HIVrelated disorders that Group I, II, and III SPs are often incorrectly viewed as "having AIDS" with the result that they unjustifiably are treated differently on the grounds of their diminished physical capacities. While AIDS in the advanced stages of infection can be disabling, most SPs and many Group IV PWAs can continue to function normally in most spheres of their life. Moveover, given the variation in the clinical course of the disease, accurate predictions about the future health of a particular SP or PWA are difficult to make. Therefore, differential treatment of such 
persons is only defensible if it is based on a careful assessment of the health of an individual PWA.

In addition to simplifying such problems, the medical information presented in Part III underscores the complexity of other AIDS-related legal issues. For example, any decision to criminalize HIV transmission raises definitional difficulties given the fact that not every incident of high risk activity results in HIV transmission. ${ }^{338}$ Thus, if the actus reus for such an offence is the actual transmission of HIV itself, it would be extremely difficult to prove under the criminal burden of proof. Of course, the act of engaging in a high risk activity by a seropositive person could itself be criminalized. While this would simplify the matter of proof, it must be recognized that such a step would be overinclusive in terms of preventing HIV transmission. Similar definitional problems arise in the context of tort law although the problem of proving causation is simplified somewhat by the less exacting burden of proof in civil cases. While an appreciation of such complexities complicates the task of the legal actor it also hopefully will contribute to a better resolution of such issues.

This paper is but a first step. It has demonstrated a range of AIDSrelated legal concerns and has identified and explained those medical aspects of AIDS most likely to be important in the legal arena. While many of the questions raised will require more detailed consideration such work must be informed by a thorough understanding of these medical issues. It is hoped that the information presented here will equip lawyers, legal academics and policy makers with the information they need to address AIDS-related problems. It must be remembered that the importance of an informed legal response to AIDS transcends the resolution of particular disputes. Such a legal response also can serve as a vehicle for educating the general public about AIDS. Not only will this help stem the spread of the disease but it hopefully will dispel much of the ignorance, prejudice and fear that underlie so many of the AIDS-related legal issues. Such public education is the ultimate solution to the legal problems of SPs and PWAs. By itself, law cannot stop the nascent "legal epidemic" described in this paper, it can only ease the suffering of its victims. 